\title{
سورة قريش دراسة تحليلية تفسيرية
}

\section{م.د بركاوي جليب}

من المعلوم أن القرآن الكريم هو كتاب اله الذي أنزله على قلب النبي الكريم(صلى اله عليه وآله وسلم) لتتضوي تحتهُ العلوم التي تشكل بمجلها العامل التشريعي إلى الناس كافة ، وهذه العلوم هي علوم القرآن الكريم المختلفة ، كان منها المنهج التحليلي / وهو من أعم المناهج وأوسعها لأنه يتتاول العلوم القرآنية من جميع جوانبها المختلفة ، وقد اخترت سورة قريش المباركة للاراسة لانها تربط بين العامل الاقتصادي والجانب الايماني لمجتمع قريش ودراسة هذه السورة جاء على وفق المنهج التحليلي ، وقد قسمت الدراسة على سبعة مطالب: المطلب الأول :نظرة عامة في السورة وقد جاء على عدة عنوانات: اولا. اسم السورة وعدد آياتها ،وكلماتها وحروفها. ثنانيا ـ سبب نزولها.

ثالثا ـ نسبتها. رابعا • صفتها.

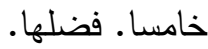
المطلب الثاني : اللغة . المطلب الثالث : الاعراب . المطلب الرابع البلاغة . المطلب الخامس : القصصي: المطلب السادس : القراءات :

المطلب السابع : مضامين ودلالة الآيات لسورة قريش المباركة. ثم ختم البحث بأهم النتائج التي توصل اليها البحث بالاعتماد على أهم المراجع والمصادر المختلفة ، وخاتمة المطاف نقول هذا جهد بشري قد يخطئ وقد يصيب فما أصاب البحث فبتوفيق من الله تعالى بـ وما أخطأت فبتقصير مني ، وآخر دعوانا أن الحمد لله رب العالمين بهِ إبتدأنا وبهِ ختمنا 
فنقول :إن سورة قريش مكية وان ذكر بعض العلماء في مؤلفاتهم وكتبهم بأن بعض آياتها

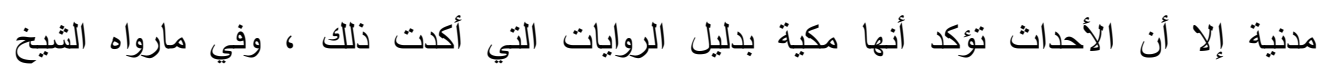

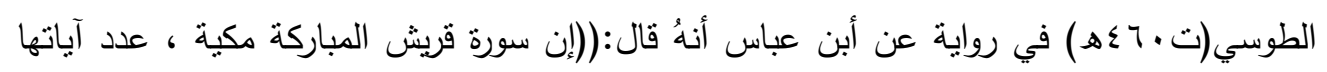

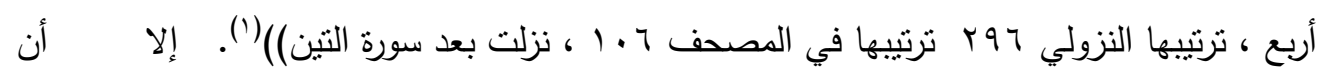

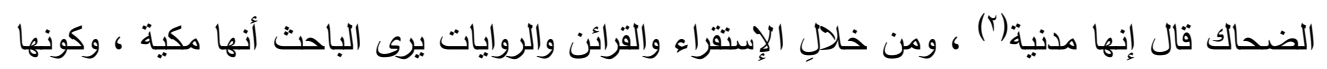

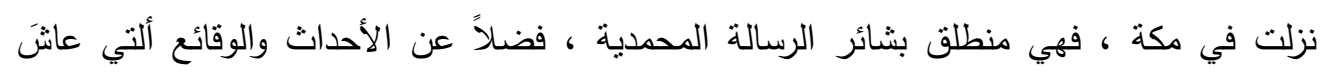

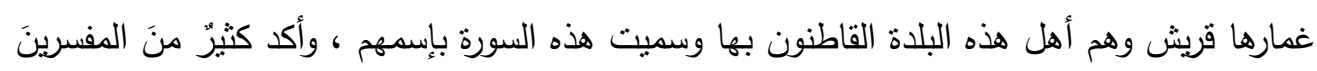
على مكيتها (").

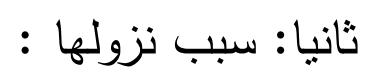

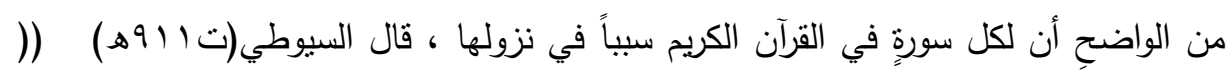

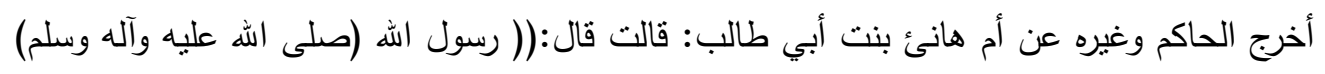

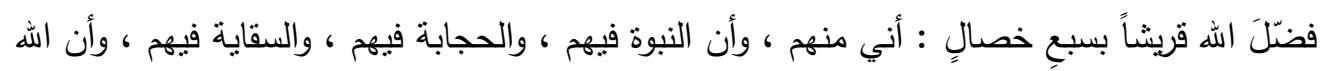

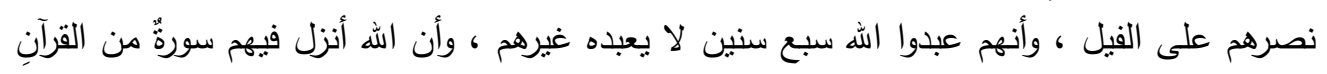

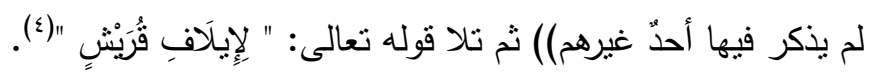

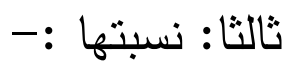

نجد أن هذه السورة المباركة نسبت وسميت باسم القبيلة المعروفة بالثجاعة والكرم والقوة ،

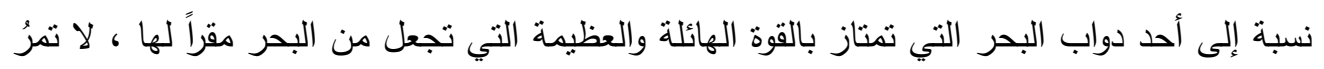
بشيء إلا أكلته وأبادتهُ ليأني رسم الصورة الحقيقية بالتثبيه في الثجاعة بين هذا الحيوان المائي وقوة 
قريش وشجاعتهم ، وكون هذه القبيلة هي منطلق الدعوة والرسالة إلى الإسلام وركيزته الأولى وأول

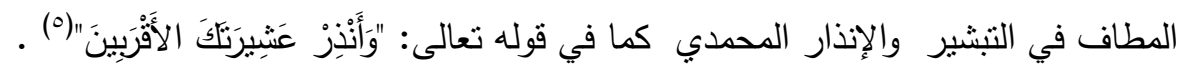

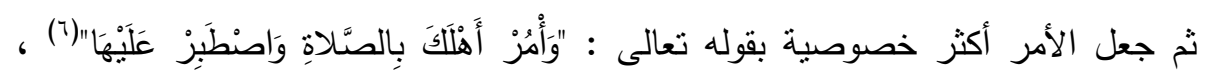

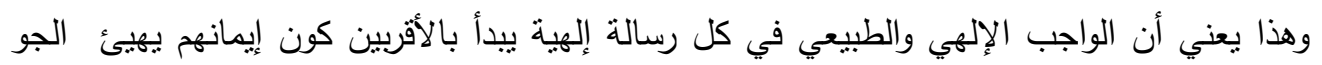

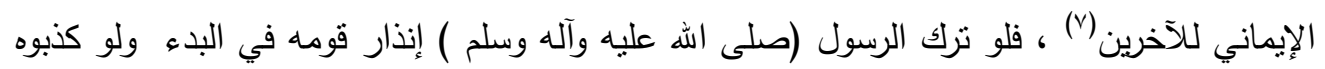

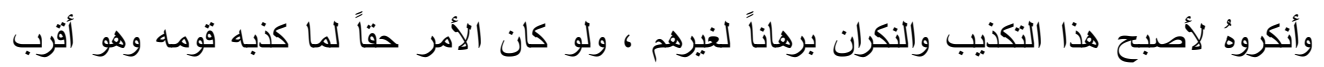

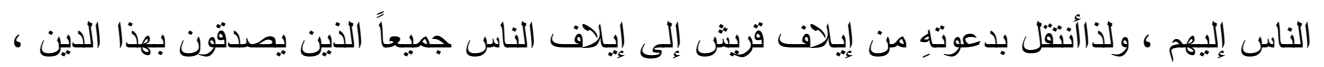

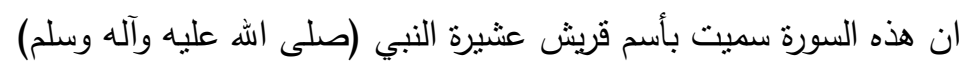

\section{رابعا: صفتها :- (1)}

قال الطبرسي(تم^§هـ) ما رواه العياشي باسناده عن المفضل بن صالح عن ابي عبد اله

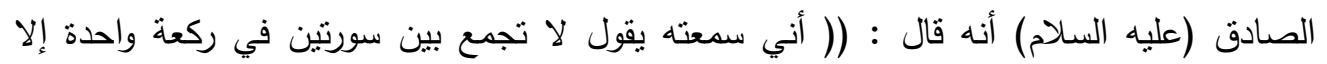

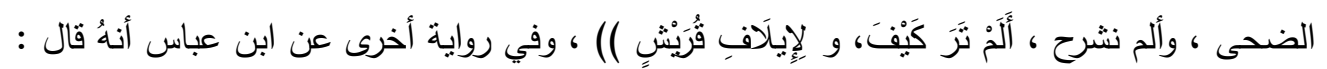

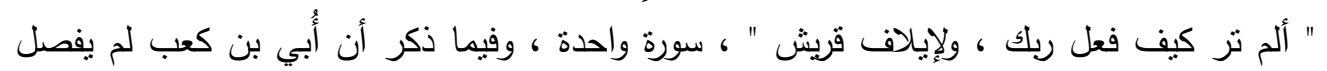
بينهما في مصحفه (^).

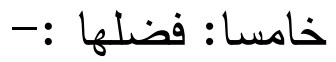

ورد في فضلِ هذه السورة المباركة روايات كثيرة تؤكد الأجر و الثواب لقارئها فما روي عن

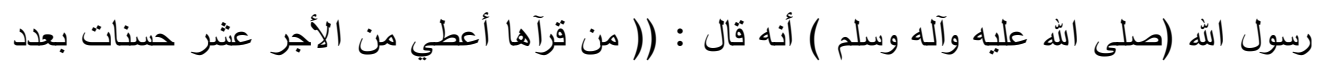

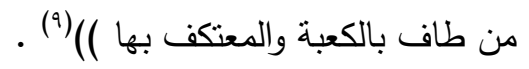


أعتتى المفسرون بالمفردات القرآنية لأنها الخطوة الأولى التي ينبغي على الدفسر أن يخطوها ،

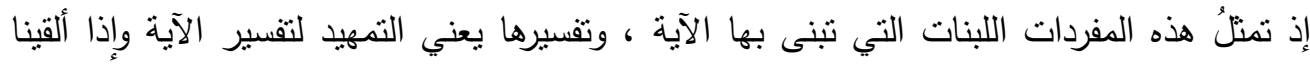

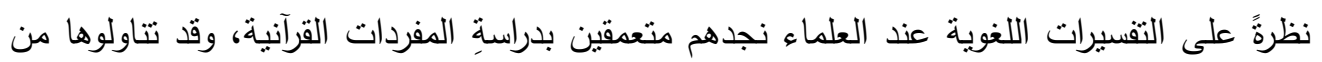
جوانب عدة : تصريف اللفظة على وجوهها المختلفة التي ترد في فائدتها ومن تفسير مفردات سورة

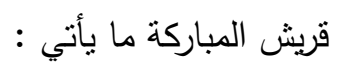

(إِلاف) :- ويقال الفتُ الموضع الفِتهُ ايلافاً ، وكذلك صورة افَعَلْ الموضَعَ أو الفهُ مؤالفةً والافاً

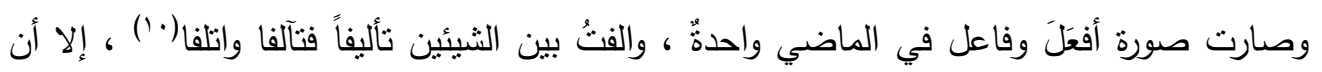

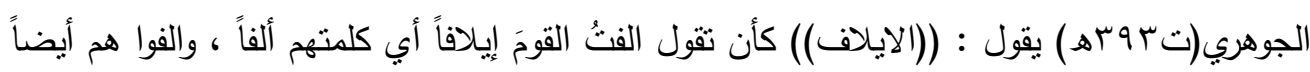

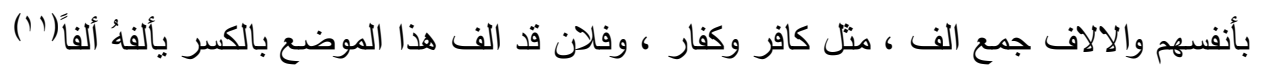
يكاد يجمع اصحاب المعاجم اللغوية على أن (ايلاف) مصدر الف ، ويقال ألفت الموضع أُلفهِ

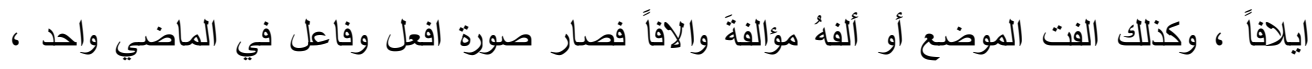

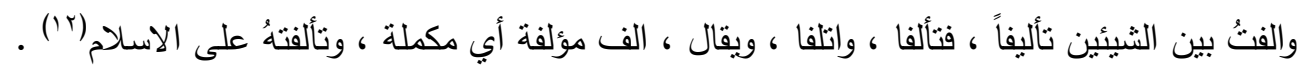

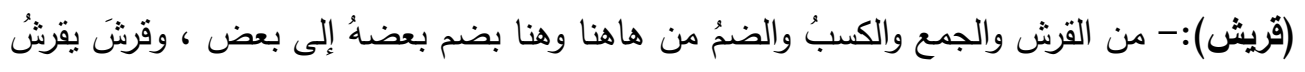

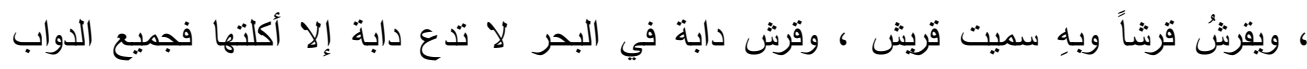

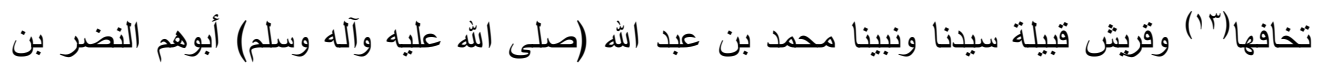

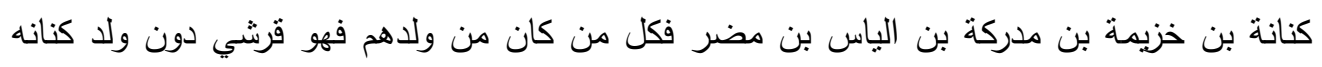

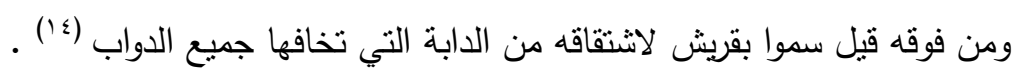
قال الثاعر :

$$
\begin{aligned}
& \text { وقريشُ هي التي تسكن البحر - بها سميثْ قريشُ قريشاً (10). } \\
& \text { وقال شاعرٌ أخر يصف قريش فقال : }
\end{aligned}
$$




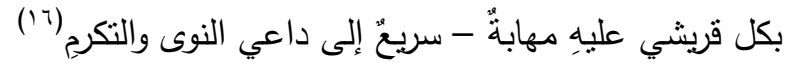

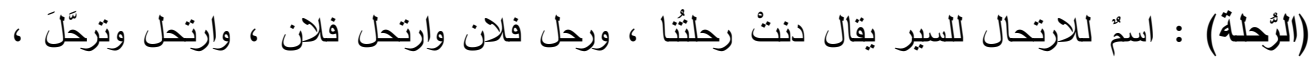

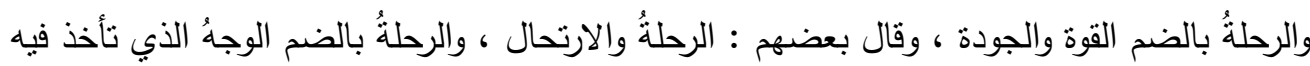

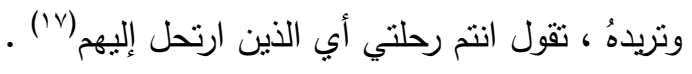

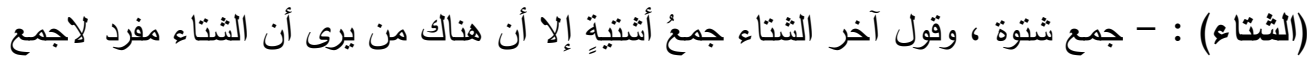

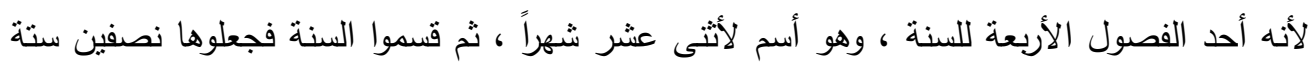
أثهر وستة أثشر ، فبدؤوا بأول السنة أول الثتاء مذكر والصيف أنثى ، الثنى ، ثم جعلوا الثنتاء نصفين

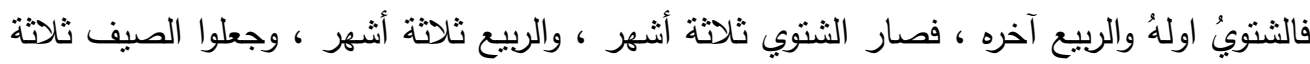

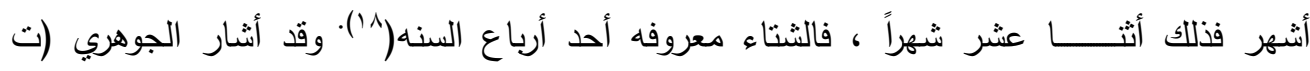

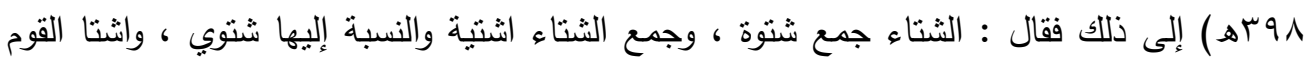

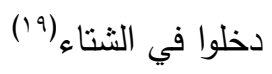

يبدو أن إثارة الجوهري لا تختلف عن ابن منظور إلا أن ابن منظور كان اكثر تفصيلاً .

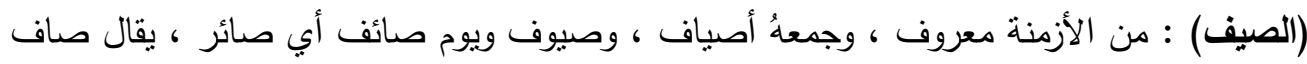

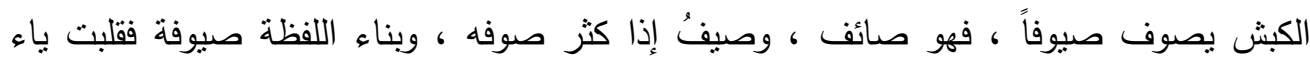

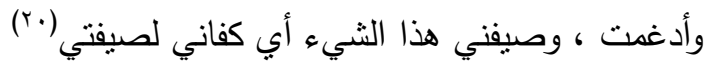

(قليعبدوا) : العبادة الطاعة والتعبد الثائع والتعبيد من قولهم ما عبد أن فعل ذلك أي ما لبث(باء) وقال

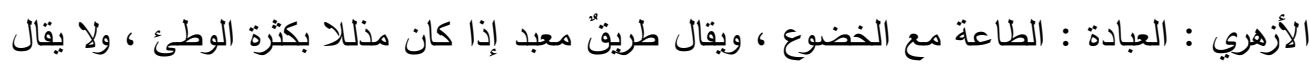

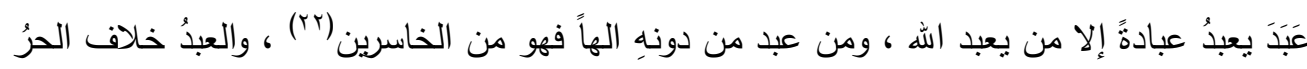

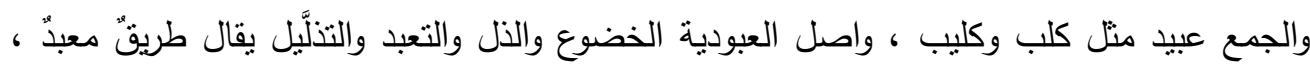
والعبادة الطاعة والتعبد الثكل (rr) .

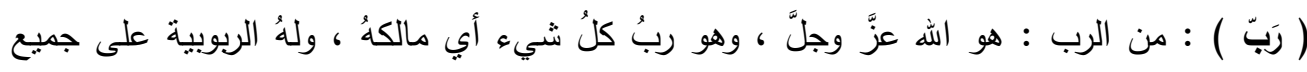

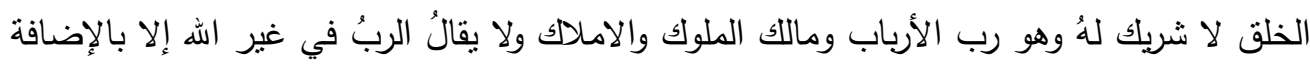


، ورب كل شيءٌ مالكه ومستحقه(؟) وعزز ذلك الجوهري فقال : (رَبَّ) هو أسم من أسماء الله

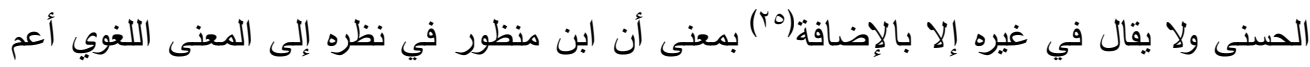

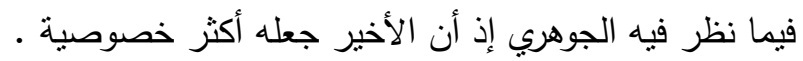

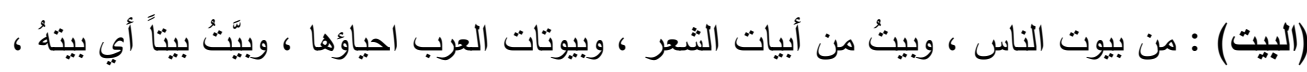

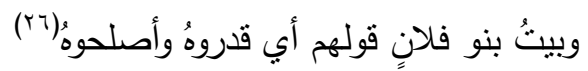

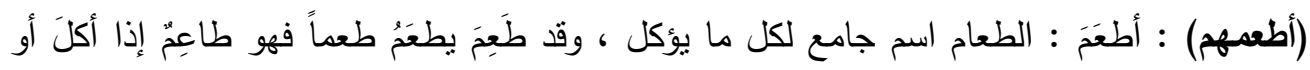

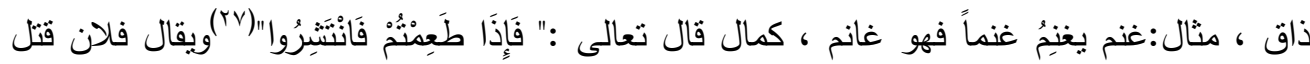

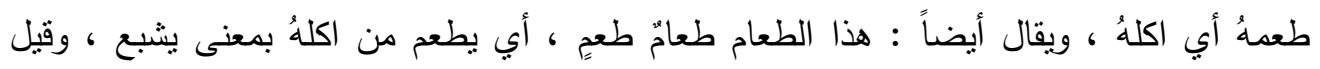

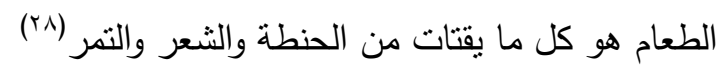

(جوع): اسم جامع للمحصة والفعل جاع يجوعُ جوعاً ، والنعتُ جائع جوعان ، والمجاعة عامة فيه

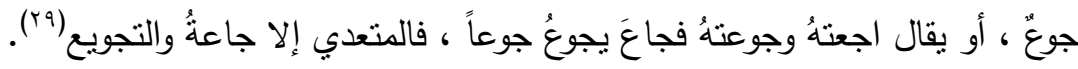

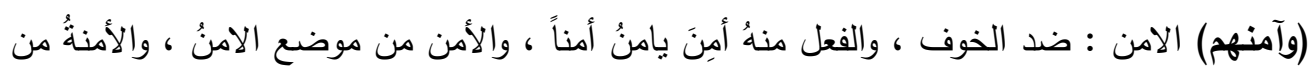
الامن اسم موضوع من امنت والأمان اعطاء الأمنة (·r) .

(خوف) : الخافة تصغيرها خويفةٌ واشتقاقها من (الخوف) وهو جنبة يكسبها العسال والسقاءُ ، والخافِة

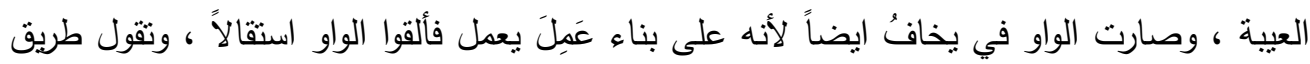

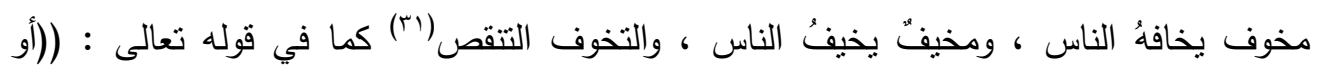

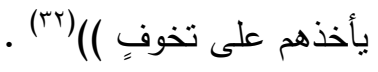

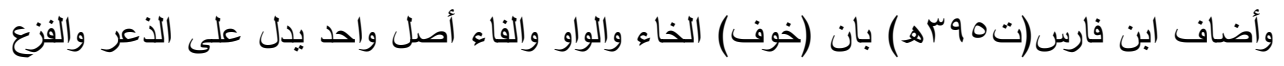

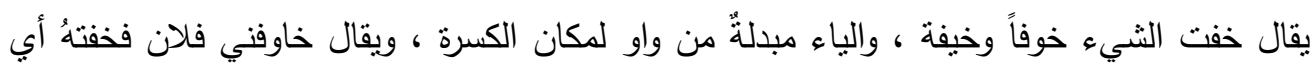

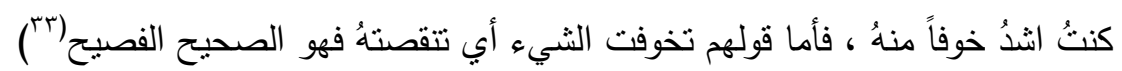


قبل الثروع باعراب هذه السورة لابد من الاشارة إلى ما ابداهُ أصحاب الثأن بذللك فمنهم من

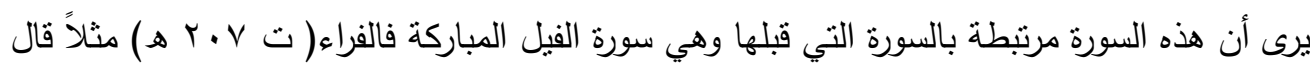

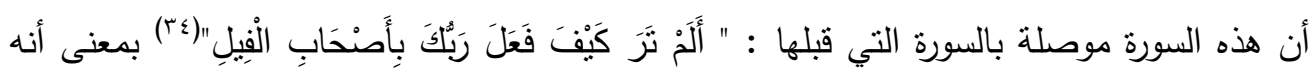
ذكر النعمة عليهم فيما صنع بملك الحبشة ، وانقاذهم من جبروتهِه ، إلى نعمة اخرى بملؤها الأمان والتحول من فترة السبات والجفاف إلى التجارة والعمل المتمثل في رحلتي الثتاء والصيف ، فكأنهُ قال نعمة إلى نعمة ، ونعمة لنعمة سواء في المعنى (ro) .

وقال سيد قطب (ت 97 (1) : إن هذه السورة تبدو امتداداً لسورة الفيل التي قبلها من ناحية موضوعها وجوها وأن كانت سورة مستقلة مبدوءة بالبسملة ، والروايات تذكر أنه يفصل بين نزول سورة الفيل وسورة قريش ، ولكن ترتيبهما في المصحف على أنهما منواليتان يتفق مع موضوعهما

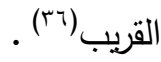

وقال الطبرسي ( ^§هـ) : (اعترض معترض فقال : انما جعلوا كعصفٍ مأكول لكفرهم ، بمعنى

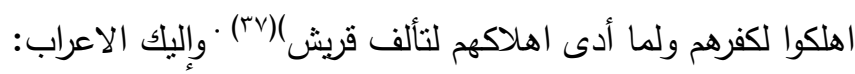

فقد اعربت (لايلاف قريش) جار ومجرور وهما متعلقان بـ (فليعبدوا) ، و (ايلافِ) مضاف مصدر ، قريش مضاف إليه مجرور وعلامة جره الكسرة الظاهرة على آخره(^؟) .

ايلاف الثانية : مصدر بدل من ايلاف الأولى مجرورة وعلامة جرها الكسرة الظاهرة تحت آخرها، وايلاف مضاف ، وهم : ضمير متصل مبني على الكسرة في محل جر مضاف إليه(9") .

رحلة : مفعول به منصوب وعلامة نصبه الفتحة الظاهرة على آخره ، ورحلة مضاف الثتاء مضاف إليه مجرور وعلامة جره الكسرة الظاهرة تحت آخره(•؛) .

(والصيف) : الواو حرف عطف ، الصيف : معطوف على الثتاء مجرور وعلامة جره الكسرة الظاهرة تحت آخره(اء)". 


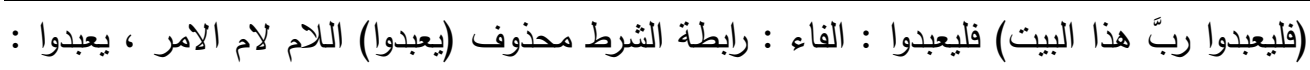

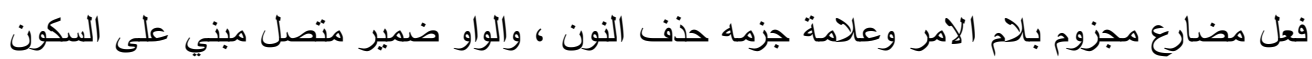

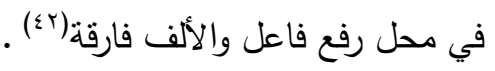

(ربَّ) مفعول به منصوب وعلامة نصبه الفتحة الظاهرة على آخره ، (ربَّ) مضاف ، هذا : اسم انشارة مبني على السكون في محل جر مضاف إليه("؟) .

البيت : بدل أو عطف بيان من إسم الإثارة مجرور وعلامة جره الكسرة الظاهرة على آخره(؛؛ .

$$
\text { (الذي أطعمهم من جوع وآمنهم من خوف) }
$$

الذي : نعت مبني على السكون في محل نصب ، وهو نعت للرب(؛).

(اطعهم) اطعم : فعل ماض مبني على الفتح والفاعل ضمير مستتز فيه جوازاً تقديره هو والهاء

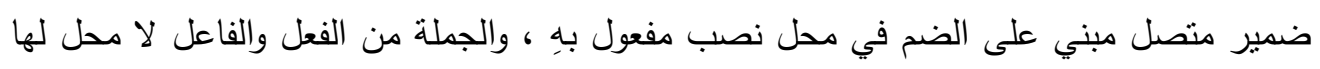

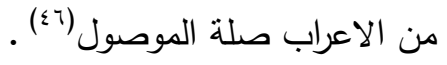

$$
\text { (من جوع) : جار ومجرور متعلقان بـ (اطعمهم) · }
$$

(وآمنهم) : الواو حرف عطف ، وآمن فعل ماض مبني على الفتح والفاعل ضمير مستتر فيه جوازاً

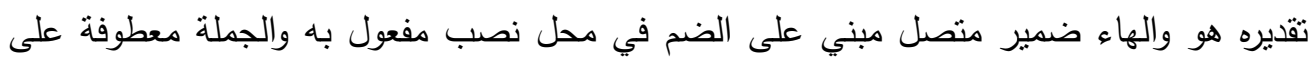

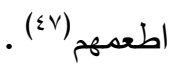
(من خوف) : جار ومجرور منعلقان بـ (آنهم) وجاء تتكير (جوع) و (خوف) لثدتهما(^) . إلا أن الباحث وجد إعراباً آخر يختلف بعض الثيء عن الاعراب أعلاه وان كان مختصراً : (لايلاف قريش) : جار ومجرور متعطق بقوله : (فليعبدوا) والايلاف مصدر (الف) ، بمعنى الف ، الف الفاد

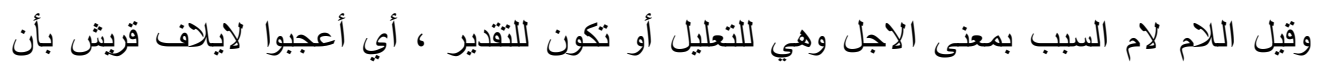

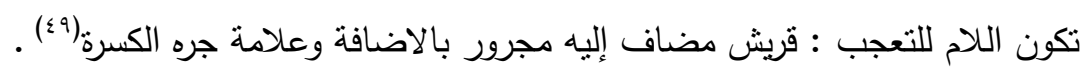


(ايلافهم رحلة الثناء والصيف) ايلافهم بدل من ايلاف الاولى مجرورة مثلها وعلامة جرها الكسرة

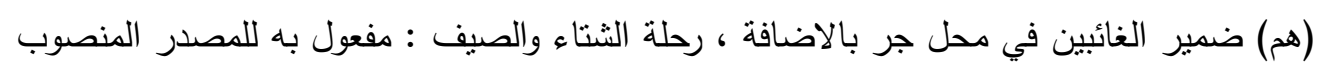

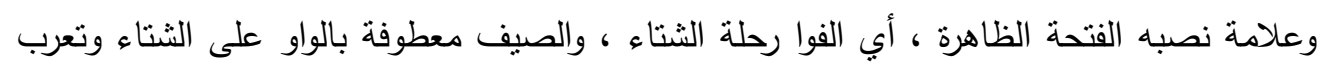

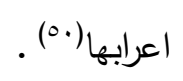

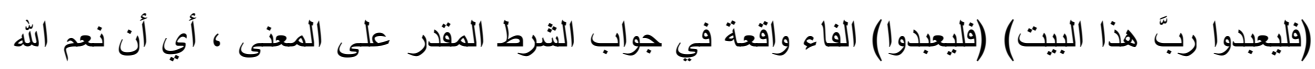

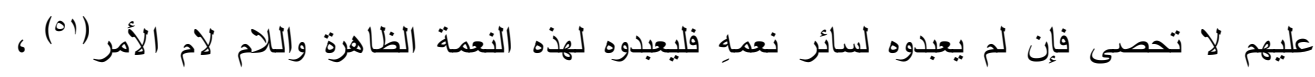

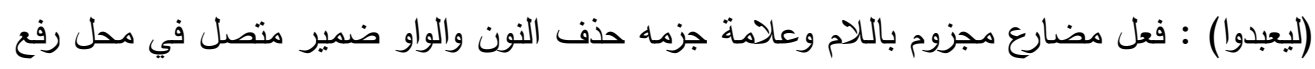

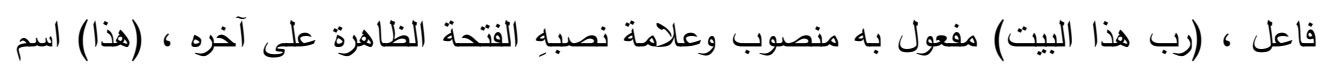

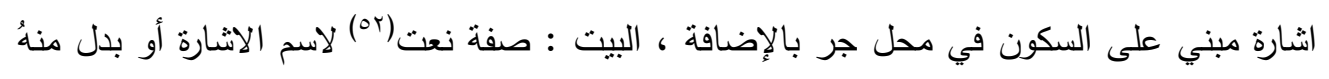

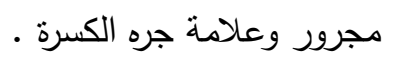

الذي : اسم موصول مبني على السكون في محل نصب صفة نعت للرب والجملة الفعلية بعده صلتهُ

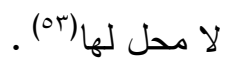

أطعمهم من جوع : فعل ماض مبني على الفتح والفاعل ضمير مستتر فيه جوازاً تقدره هو. (هم) ضمير الغائبين في محل نصب مفعولٌ به ، من جوع : جار ومجرور متعلق بأطعمه أي

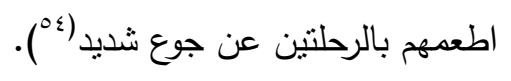

(وآمنهم من خوف) : معطوفة بالواو على أطعمهم من جوع ، وتعرب أعرابها ، وقيل (من) بمعنى

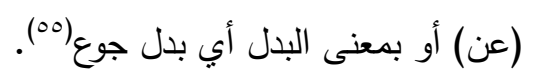

يبدو من خلال الموازنة بين الاتجاهين في اعراب آيات السورة المباركة ، ففي الاتجاه الاول

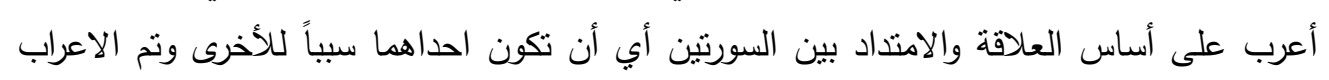

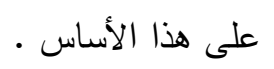




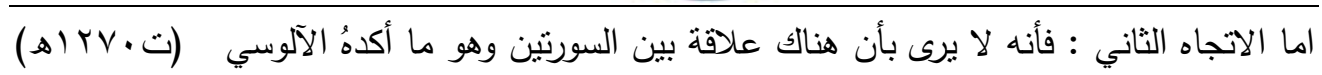

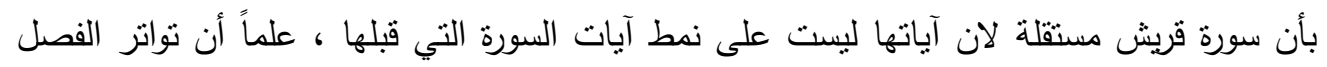

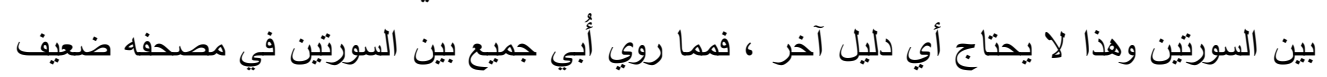

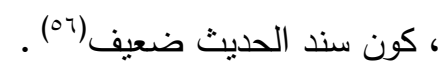

وفي نظر الباحث أن أصحاب الاتجاه الأول هم الارجح على الرغم من أن لكل سورة استقلاليتها

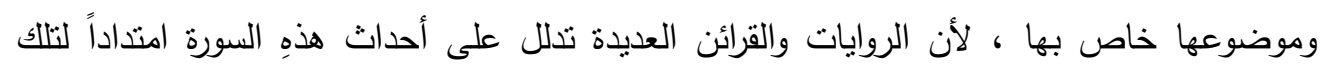

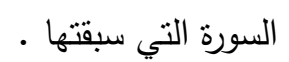

\section{المطلب الرابع: البلاغة :-}

لو بحثنا عن لفظة البلاغة في النزاث العربي لوجدنا أنها لفظةٌ شائعةٌ معروفةٌ وقد جاء ذكرها

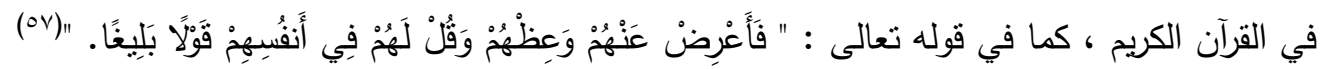

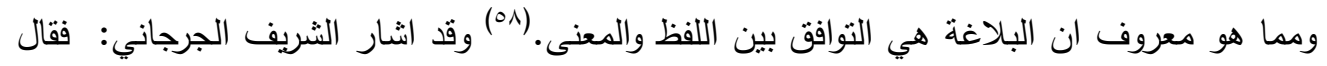

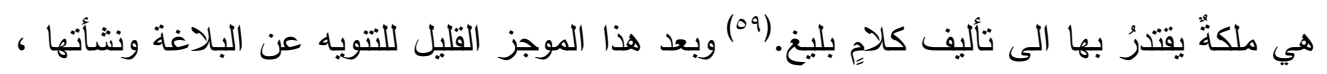

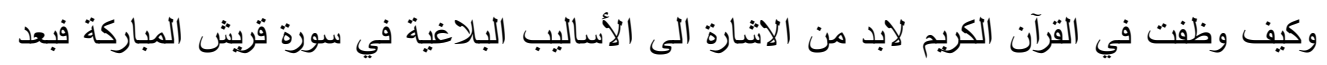

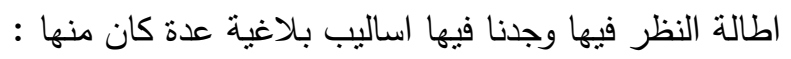

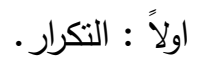

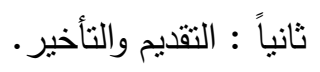

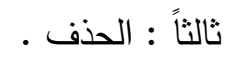
رابعاً : الامر . الحزف خامساً : الكناية . سادساً : التعريف والتتكير . لاكنة . سابعاً : الطباق .

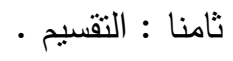
تاسعاً : الفصل والوصل. 
ويمكن معرفة هذه الاساليب من خلال تعريفاتها مع توظيف الايات الخاصة في كل اسلوب من

\section{مجلــــة كليــــة التربيــــة}

$$
\text { السورة المباركة التي هي محط ركاب البحث وكما يأتي : }
$$

$$
\text { 1- التكرار :-- هو عبارة عن الاتيان بثيء مرة بعد أخرى(.٪) وهو ملمع بديعي في قوله : }
$$

" لإيـافِ قُرَبْشٍ إِيلافِهِْ" الآية ذكر لفظة ايلاف وذللك لإعطاء زمن امتدادي قادر على جذب المنلقى ، والمحافظة على الرصد والمتابعة ، ولاسيما أنها في باب الخطاب الموجه للتنكير بنعم الله تعالى ،

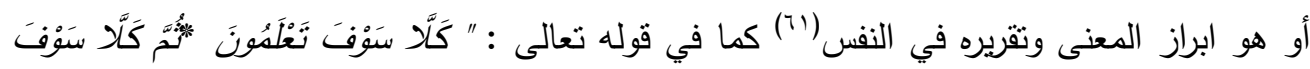

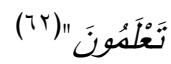

ץ- التقديم والتأخير :- قال الدكتور قصي سالم علوان ، إنهما ركنان في الجملة لأغراض بلاغية(rآ) ، ثم أثنار بعد ذلك إلى أهمية التقديم والتأخير في التأثير من حيث التمهيد والتشويق، في أول الكلام لما يأتي بعده ولما يكون فيه اصابة الغرض بالتعبير المناسب ، بمعنى آخر أنه ليس اعلامك الثيء

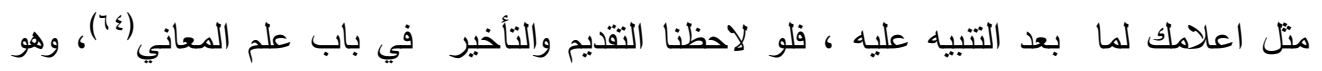

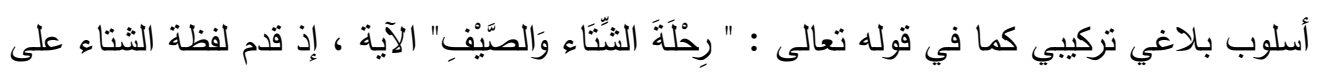
لفظة الصيف ، لأنها الأقسى والأصعب ، فالثتاء في قساوته على البدوي أثند من الصيف لأن في الثتاء الجرب ، ورغم ذلك أراد النص القرآني أن بيين فضل الله تعالى في نعمه في الجرب وغير الجرب على أهل مكة ، وإنما جيء به لباب التقرير والتذكير •

ب- الحذف ، باب علم المعاني : عرف الحذف اصطلاحاً أنهُ اسقاط سبب خفيف منل (لن) من مفاعيلن ، ليبقى (مفاعي) فينقل إلى (فعولن) ، ويحذف (لن) من (فعولن) ليبقى (فعو) فينتقل إلى الى

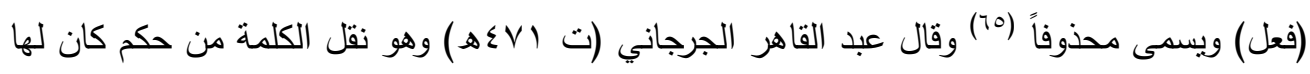

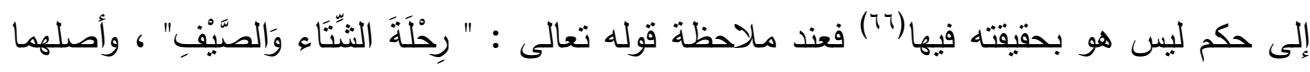

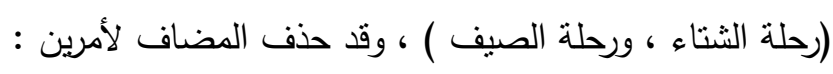

الأول الايجاز ، وهو ركن مهم من أركان بلاغة النص ، والثاني واله أعلم أن الرحلة ذُكرت مع ، فع ، الشتاء للأهمية ، فرحلة الشتاء أقسى وأهم من رحلة الصيف في ظروف الصحراء . 


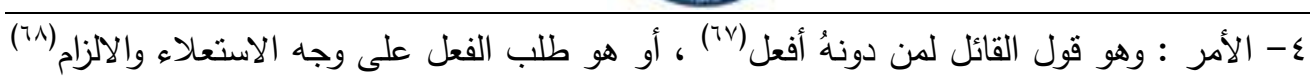

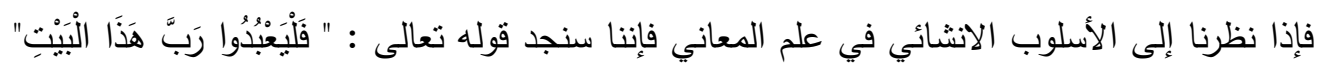
الآية إنما جيء به بصيغة (ليفعل) للارشاد ، كذلك فيه جوانب مجازية التذكير بنعم الله سبحانهُ وتعالى على أهل مكة .

يبدو أن هذه الصيغة قد جاءت على صيغة الفعل المضارع لتعطي طابع التجسيد الصوري لأهمية العبادة وضرورتها ، وكذلك جاءت مضارعة لإعطاء معنى الاستمرارية والتجدد في فعل هده

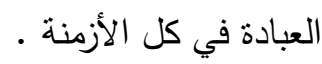

ه- الكناية عن موصوف : كلام استتز المراد منهُ بالاستعمال وان كان معناه ظاهراً في اللغة سواء أكان المراد به الحقيقة أو المجاز ، وفي معنى آخر وهي أن يعبر عن شيء لفظاً كان أو معنى ،

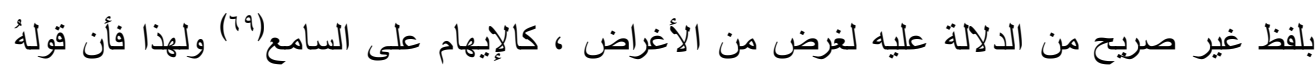
تعالى : " رَبَّ هَذَا الَبَيْتِ " الآية كناية عن موصوف هو ((الله جل جلالهه)) ، وانما جيء بـِهِ والله أعلم

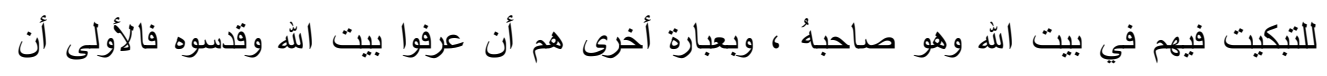
يقدسوا صاحبه (جل وعلا) .

ج- التعريف والتتكير : المعرفة ما دلت على شيء بعينهِ ، والنكرة : ما دلت على شيء لا بعينه(•) ففي قوله تعالى (( هذا البيت)) الآية استخدم القرآن الكريم دلالة التعريف المكانية وعظم شأنهُ في بعين نفوس قريش والله أعلم فئ فئ

V- الطباق : وهي من المطابقة ، وتعني الموافقة ، والتطابق أي الاتفاق ، وطابق بين الثيئين ، أي

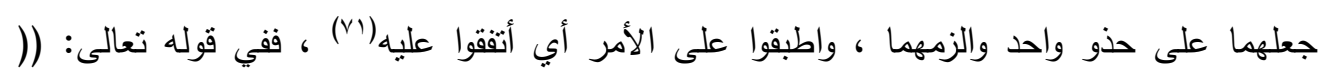
الثتاء ، والصيف) ،اذ يعمل فيهما جانبان جانب موسيقي وجانب دلالي إذ يعمل على وضع نقاط بين المتضادات ليتم فرز الفارق ليتبين عظمة ورحمة الله سبحانه وتعالى إلآ أن الدكتور أحمد قاسم قال : ( هو الجمع بين الضدين أو المعنيين المتقابليين في الجملة)(Vr) . 
1- التقسيم : هو فن من فنون البديع وهو يرد في الكلام على عدة صور تختلف كل صور منها عن الأخرى( (VT) ، أسلوب بديعي صحيح ومستوفي ، فأهم نعمنين على الانسان هما نعمة الطعام (الرزق)

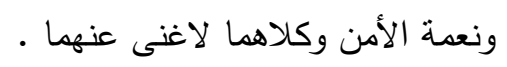

9- الفصل والوصل : فالفصل : هو كلي في جواب أي شيء هو في جوهره كالناطق والحساس(£(V. أما الفصل : فهو عطف بعض الجمل على البعض ، فإذا أمعنا النظر في قوله تعالى : "فَلَيَعْبُوُوا

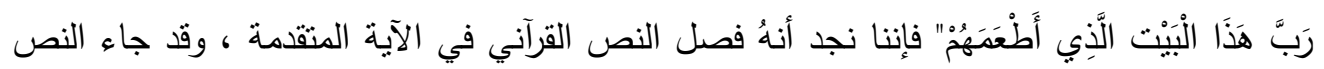
فيه الفصل ليعطي معنى التفضيل لنعم الله وهي (الذي أطعهم من جوع وآمنهم من خوف)

\section{المطلب الخامس: القصصي :}

من ينظر ويتمعن ويطيل التدبر في القرآن الكريم يجد أن القصص فيه جاءت بطريقة منوالية يعجز العقل عن إدراك السر فيها إلا الله تعالى إذ جعل أحداث بعض السور سبباً للسور الأخرى ، أو

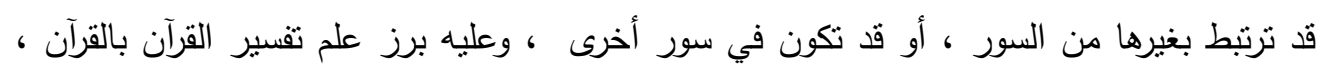
وإن لم يكن موضوع البحث ، ففي سورة قريش المباركة نرى إظهار عظمة الله تعالى وحقانية دينه

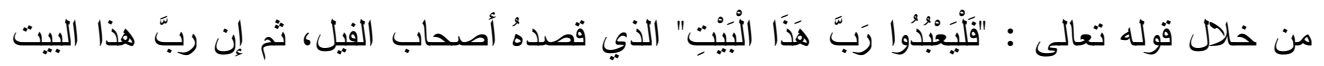
دفعهم عن مقصودهم لأجل إيلافكم ونفعكم ، لأن الأمر بالعبادة إنما يحسن مرتباً على إيصال المنفعة

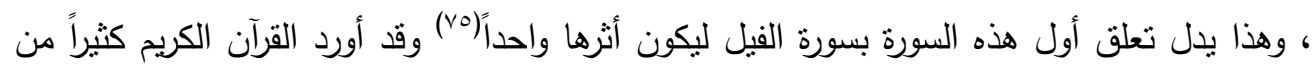
القصص المملوءة بالأحداث التي عاشتها الأمم السابقة ، لتكون حجة الأنبياء والرسل بوجه المتمردين والأعداء ، لذلك جاء عقابه الاعجازي مختلفاً عن العقاب الآخر الذي وقع ، أو يقع على أمةٍ أخرى

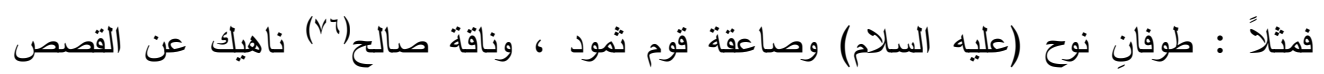
والأحداث ألتي جاءت ليحرك من خلالها الذهن الإنساني ، وليوقظ عقل الجبابرة المتمردين في توماتي الأرض ، بأن قدرة الله تعالى فوق قدرتهم ، اذن فكيف يتصور المرء أن مجموعة من الطيور الصغيرة

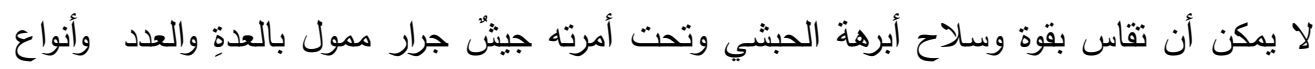
السلاح ، جاء لهدم الكعبة وإزالتها ، متتاسياً أن الله تعالى ( لبالمرصاد) إذ إنه جلَّ وعلا أمر الطيور الصغيرة بأن تحمل كل واحدةٍ منها حجراً صغيراً لتفتك من خلاله أبرهة وجيشه ، ولتجعله كعصف

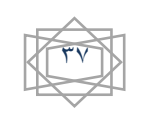


مأكول ، وليوقظ خلاله عقلية جبابرة قريش الذين عاشوا قصة أصحاب الفيل ، وراحوا ينكرون رسالة

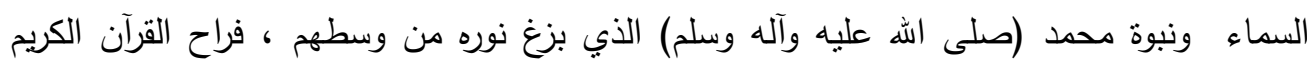

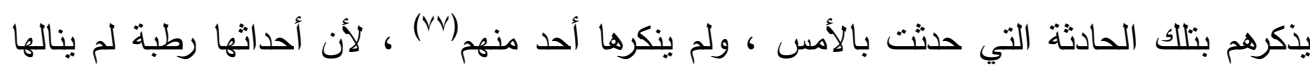

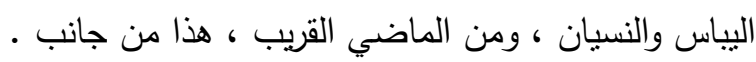

اماالجانب الآخر فإنَ اله تعالى بَينَ لطفه ومحبته لهم بأن جعل هذه الرسالة السماوية تتطلق

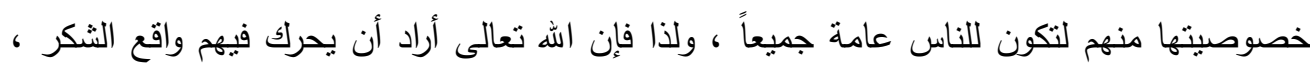

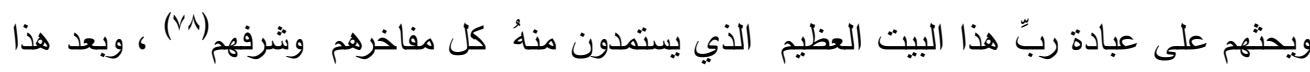
كله أجد أن أحداث سورة قريش المباركة ذكرت بأحداث قصة أصحاب الفيل الذين جاءوا بجيش جرار يقودهم أبرهة الحبشي لإزالة وهدم الكعبة ، وهم قادمون من اليمن يمنطون الفئ الفيلة متتاسين قدرة

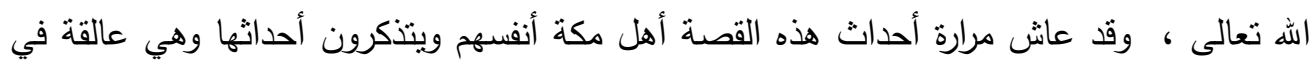
أذهانهم ، وعليه فعندما جاءت البشرى والأمر الإلهي بوجوب بيعة منقذ البشرية من الظلام والكفر

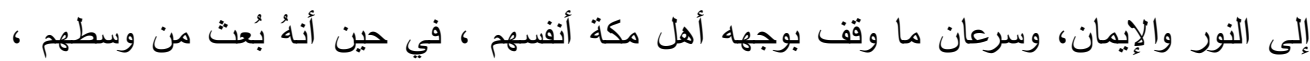

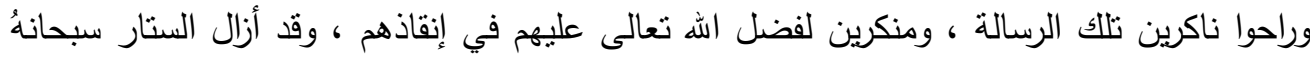

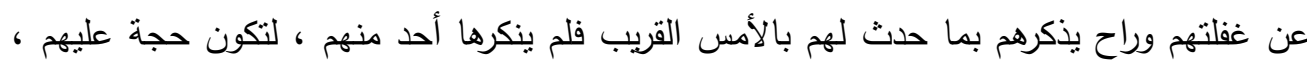

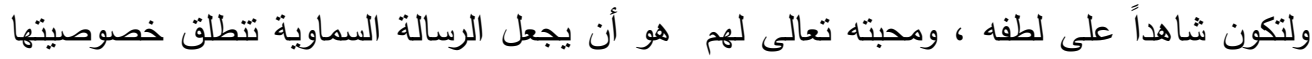

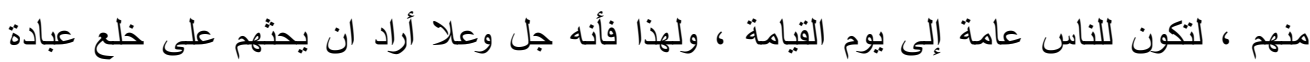

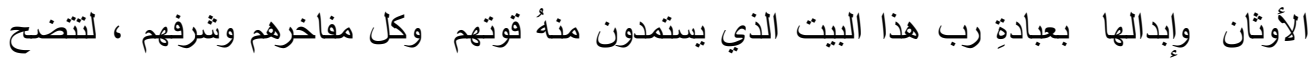

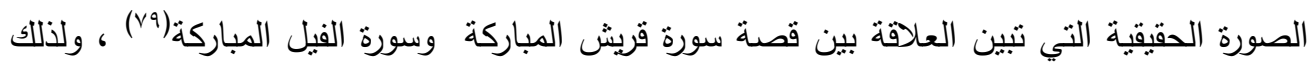

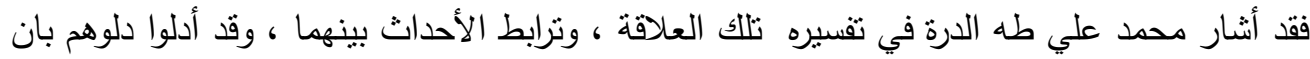

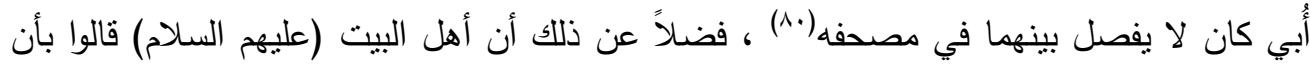

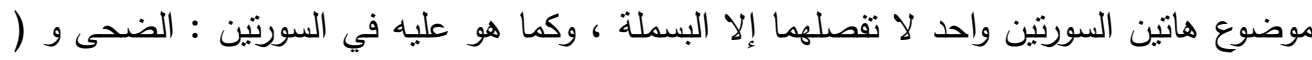

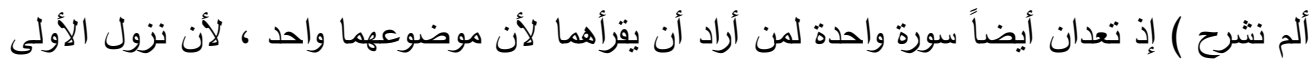

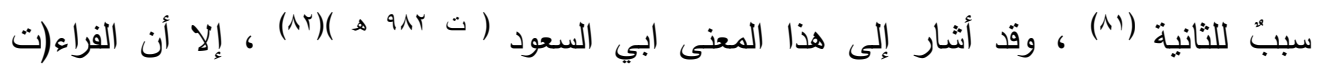

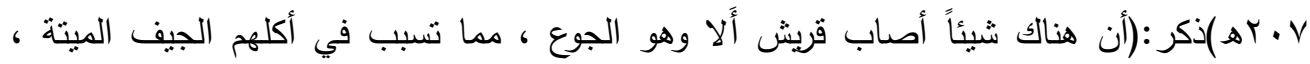


فأخصبت الثام فحموا إلى الأبطح وأخصبت اليمن فحملوا إلى جده ، فأتاهم الرز من الجهتين

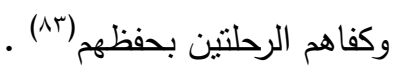

وتذكر قصة أخرى بأن أهل مكة أصييوا بالجذام ، فأثفاهم اله منه وكفاهم ذلك فلم يكون

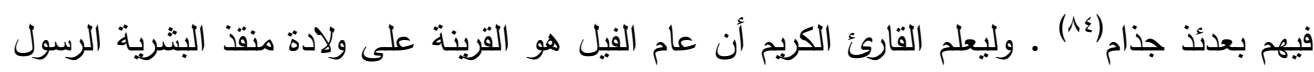

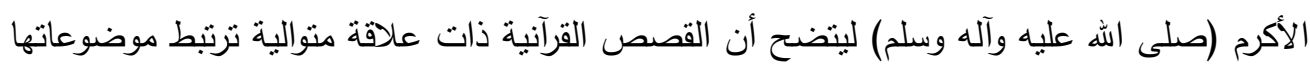

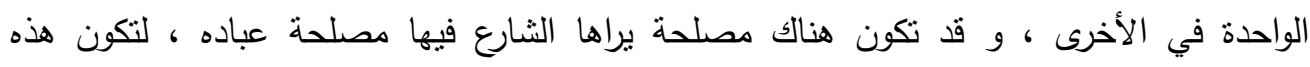

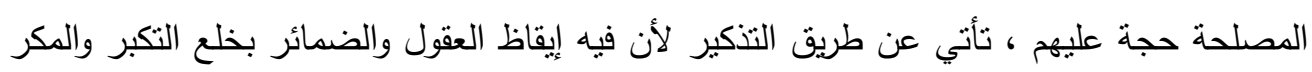

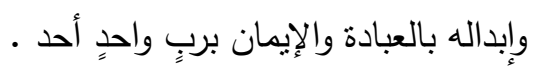




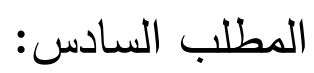

إن متتع القرائن التي تتحدث عن القراءات يجد أن الاختلاف في اللهجات قد يكون سبياً

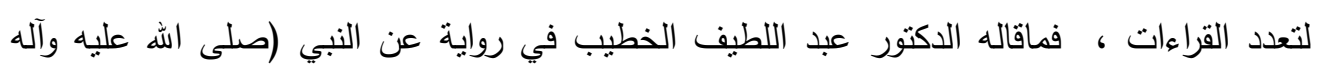

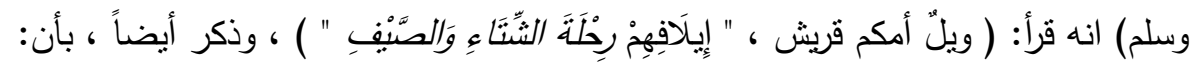

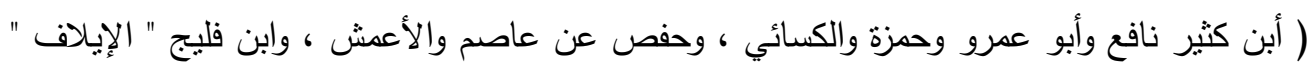

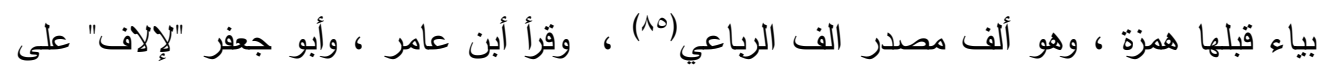

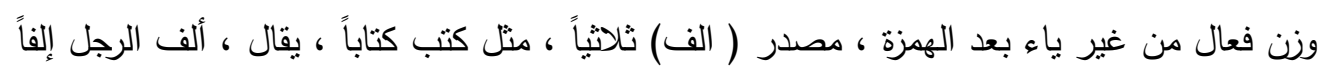
وإِإفاً

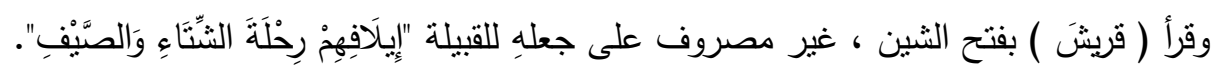

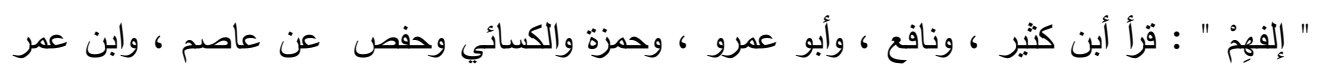

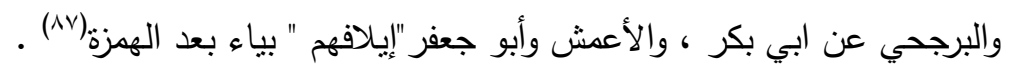

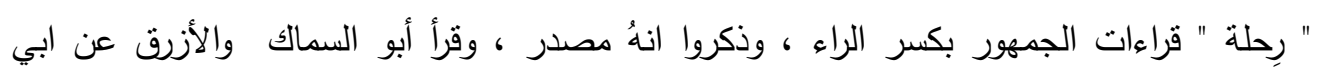

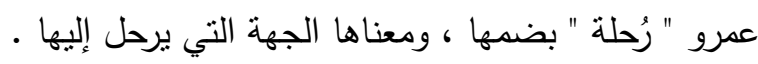
" الثنتاء " إمالةٍ ، ونصير عن الكسائي ، وهبيرة(^) . .

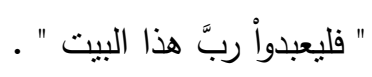

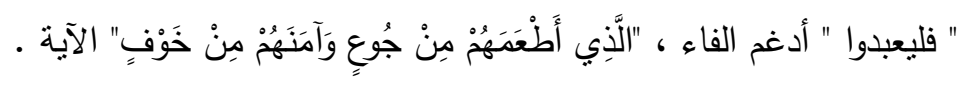

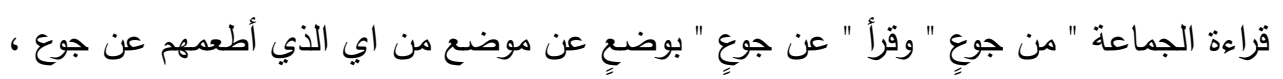

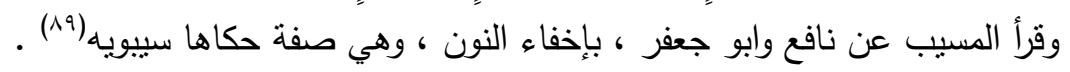

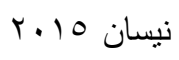

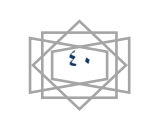


وبعد هذا بتضح أن هذه القراءات وان اختلفت بعض الثيء إلا أنها تلتقي في نقطة واحدة ألا

وهي اللغة العربية التي نزل بها القرآن الكريم وهو خاتم الكتب السماوية ، واللغة العربية خاتمة إلته اللغات كرمها الله تعالى بالقرآن الكريم وجعلها قاعدة ينطلق بها مرشداً موجهاً للناس كافة. 


\section{مضامين و دلالة الآيات لسورة قريش المباركة :}

من المعروف أن التفسير هو اجل العلوم قدراً ، كونه المفصل الى مراد اله تعالى من كتابهِ ،

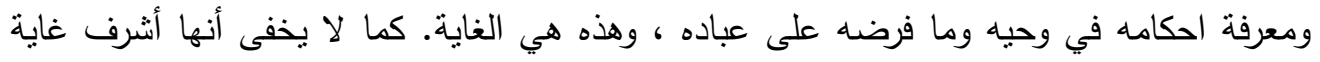

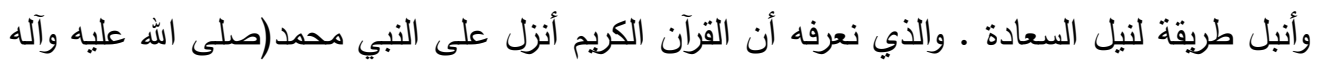

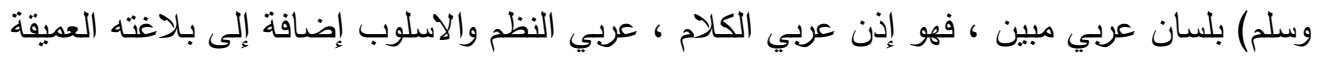

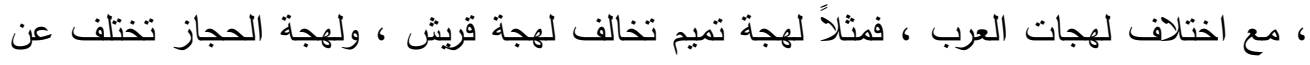

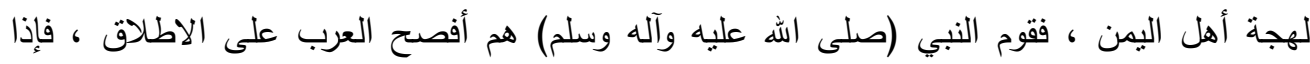

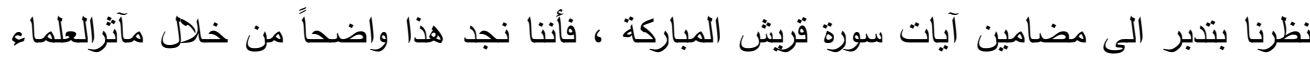

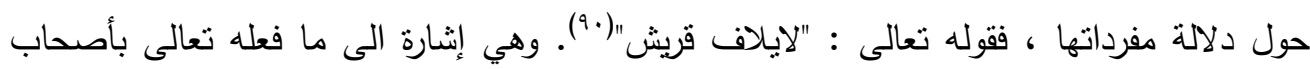

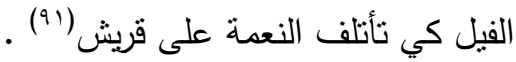

يبدو للباحث أن المعنى في قوله تعالى قد برز من غيره لأن هذه السورة ارتبطت بما قبلها

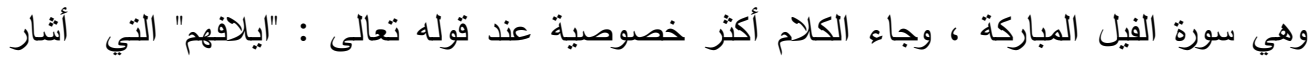

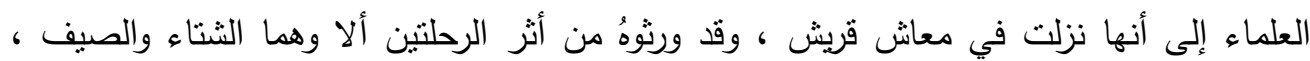

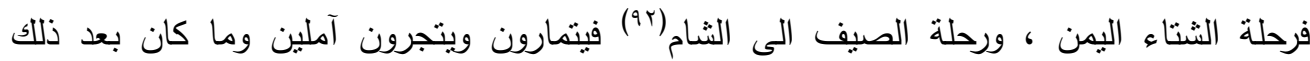

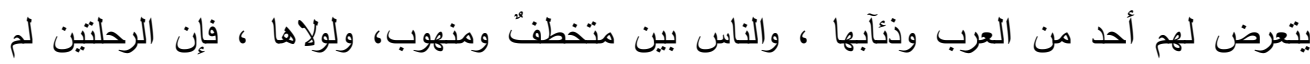

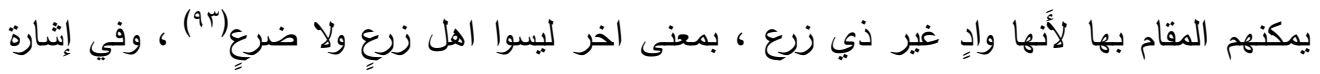

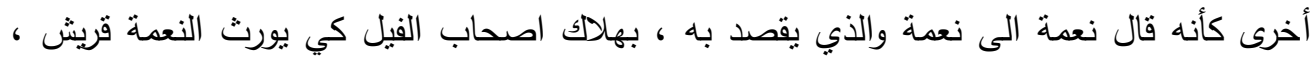

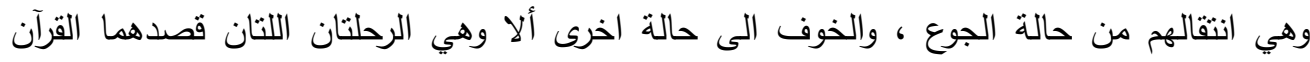

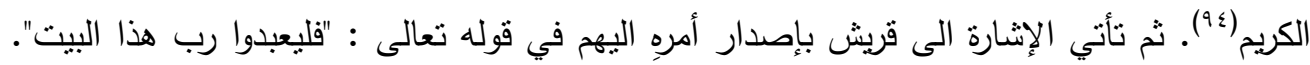

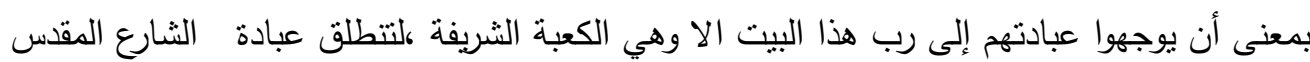

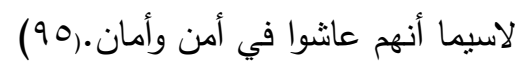


وكما يتضح من ذلك أن الحفاظ على بيت اله ، وهو بيت عزهم ، وسيادتهم وكونه جذب إليهم ثمرات كل شيء ،ولان الثارع المقد خصَ قريش بالرسالة فأختار محدد بن عبد الهه (صلى اله عليه

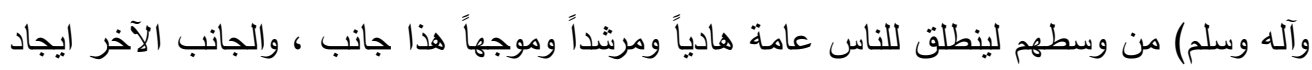

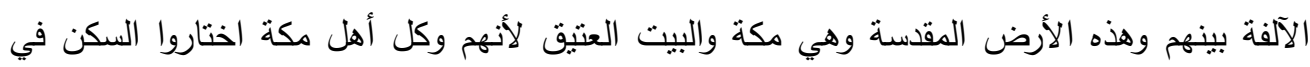
هذه الأرض لككانتها وأمنها ،حيث أن الكثير من أهل الحجاز كانوا يحجون البيت كل سنة وليته ويقترن

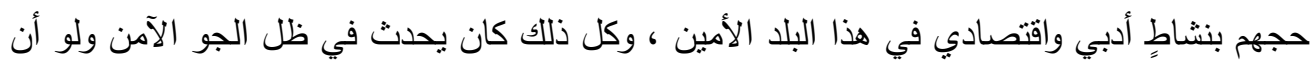

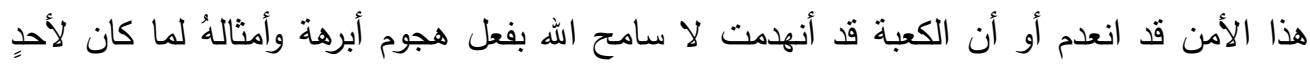

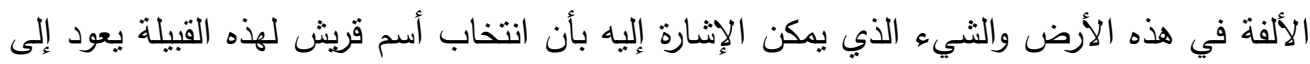

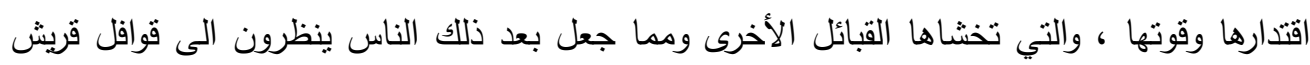

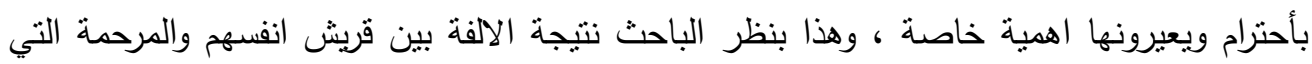

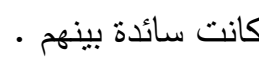

ثم قال تعالى : "الذي اطعهمه من جوع وامنهم من خوف" الا وهي اشارة الى لفظتين شديدتين في

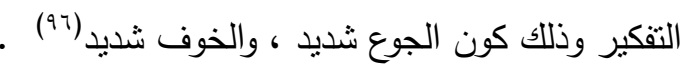

يبدو أن مضامين دلالة ايات سورة قريش المباركة مترابطة لا تتفك بعضها عن بعض ، فإذا

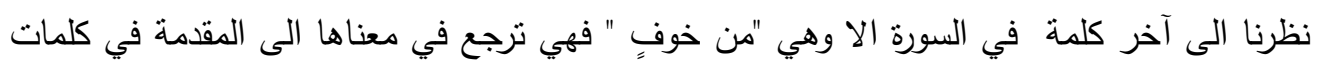

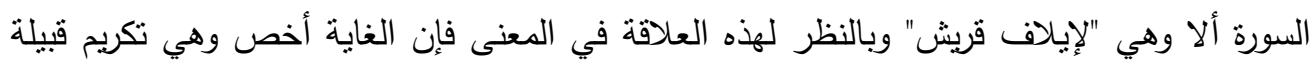
قريش وهي قييلة الرسول الكريم (صلى الله عليه وآله وسلم ) . 
ا . عندالرجوع الى آيات السورة المباركة أجدها تؤكدعلى الجانب التوقيفي في اطلاق اسم السورة وتسميتها بإسم عثيرة الرسول الرسول الكريم (صلى اله عليه وآله وسلم)اضافة الى علاقتها في سورة

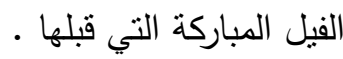

r. الاحداث التي جرت في فترة عصيبة مرت على المجتمع المكي كان منها الاعتداء الحبثي والجفاف الذي عاناه انذاك،عدت فترةُ مخاظٍ عسيرة ومثقاربة، لينتقل بعدها إلى حياةٍ جديدة يملؤها

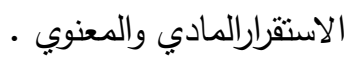

r. قوة الشخصية الفذة والروحية العاليةالمتمثلة بشخصية الرسول الكريم(صلى اله عليه وآله وسلم) وكيف احتوى بقلبه الكبيرعنادالكفارمن قومه وشجاعته في الانتصارعليهم على الرغم من قلة المناصرين له.

ـ ـ الاساليب البلاغية المتعددة والمختلفة التي تمتازبها السورة المباركة .

ه. الاحداث التي تلاها القرآن الكريم وهي قصص الانبياء السابقين (عليهم السلام) تسلية لرسوله الكريم(صلى الله عليه وآله وسلم) واثرها في تثبيت قلب النبي في نشر الدعوة الى الاسلام. 7. القرآن عربي الكلام ، عربي النظم عالمي الدلالة والاسلوب اضافة الى بلاغته العميقة مع اختلاف لهجات العرب. 


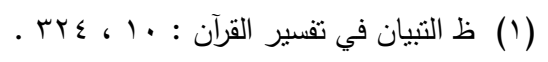

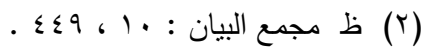

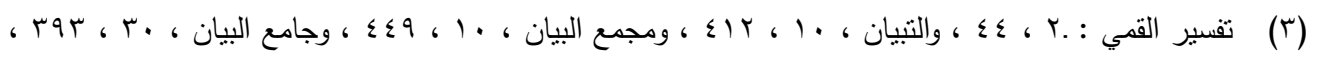

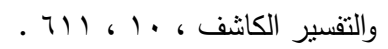

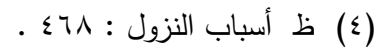

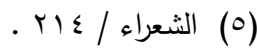

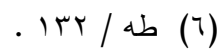

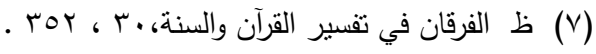

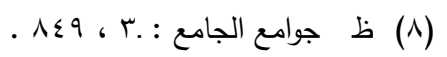

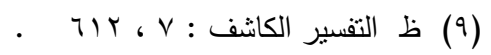

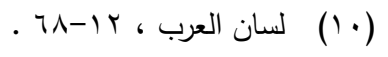

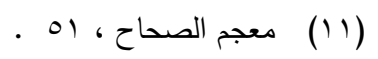

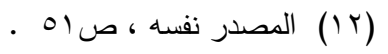

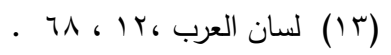

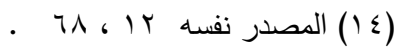

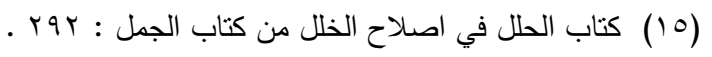

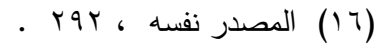

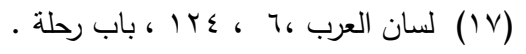

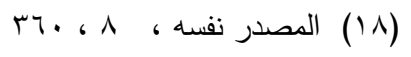

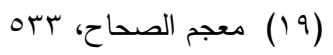

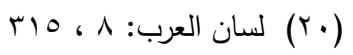

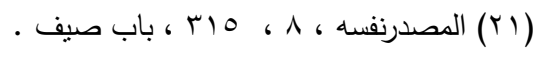

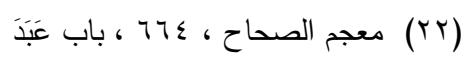

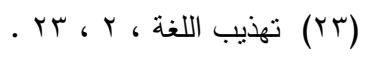

.

(Y0)

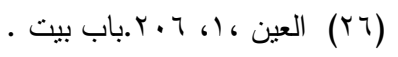

. بالاحزاب/rV)

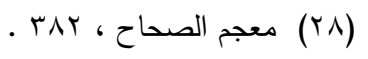

نيسان 10 


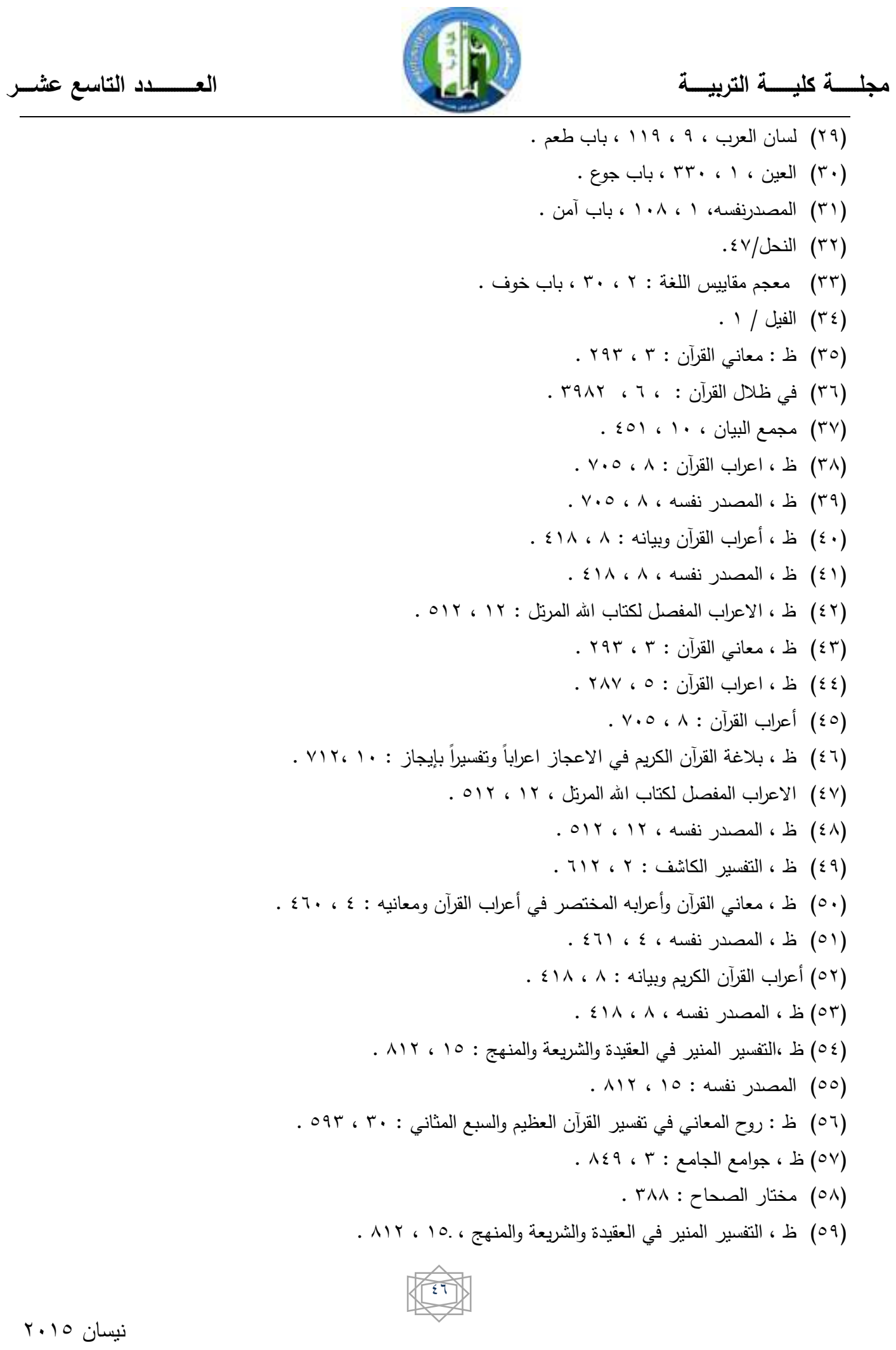




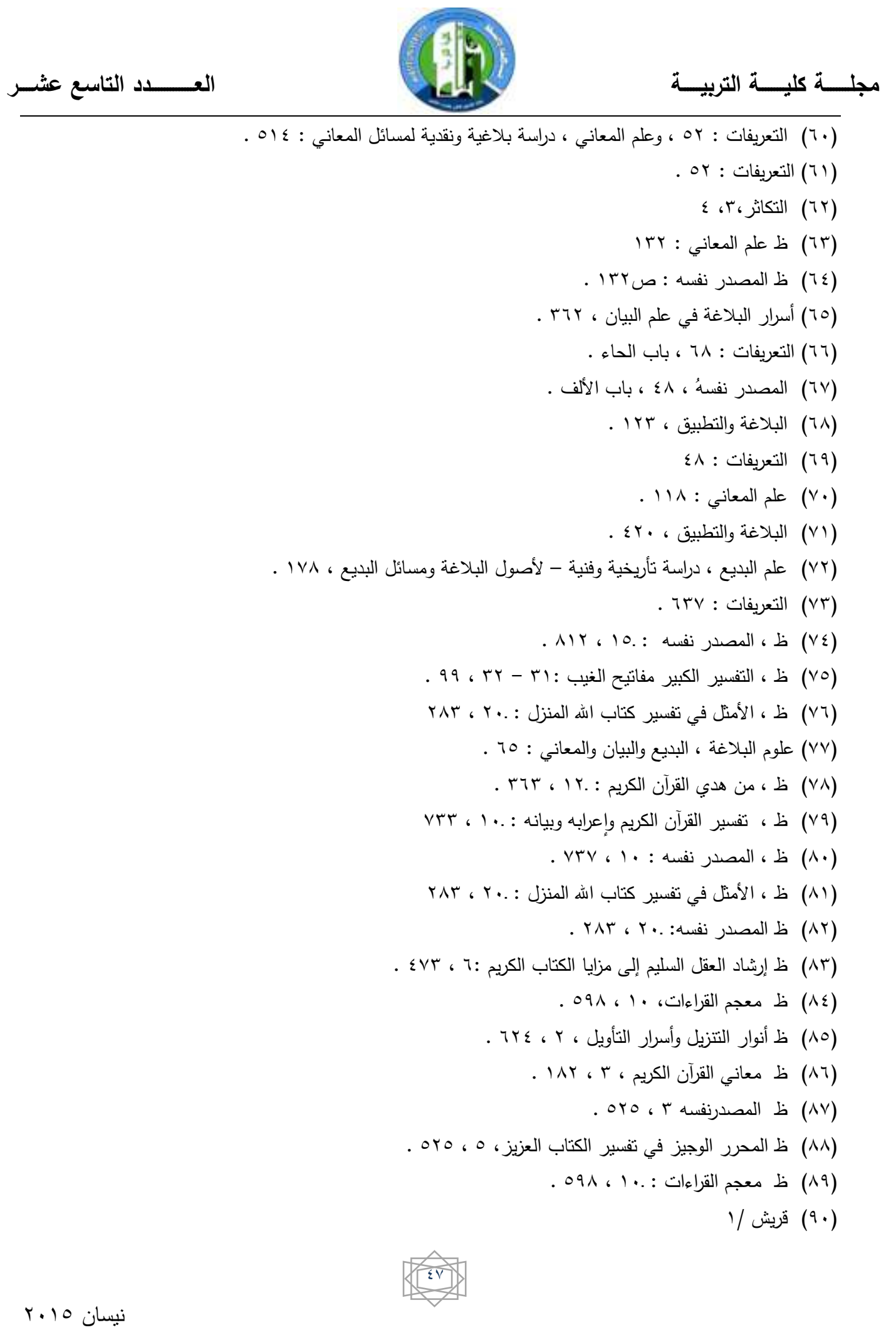




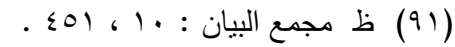

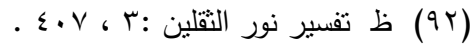

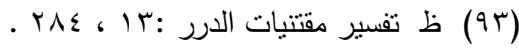

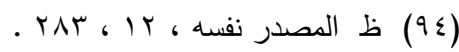

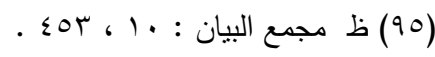

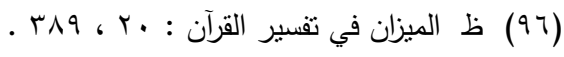


خير ما نبتدأ به القرآن الكريم

1- ابحاث في بلاغة القرآن : محمد كريم الكواز ـ لم تذكر الطبعة ومكان الطبع وسنة الطبع.

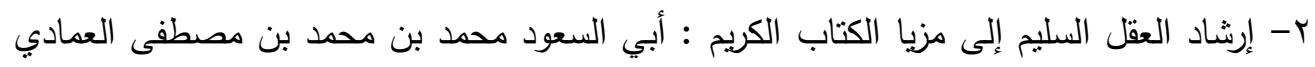

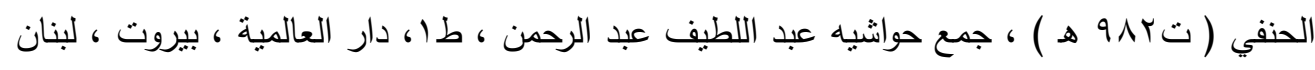
. م) r- اسباب النزول : جلال الدين السيوطي (ت (1) 9 هـ ) ) : تحقيق حامد أحمد الطاهر ، طا ، دار

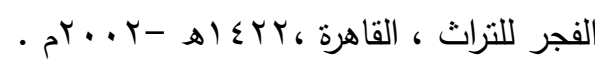

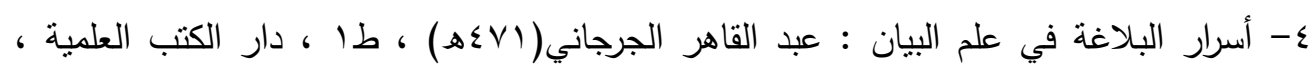

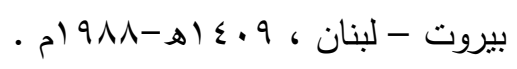

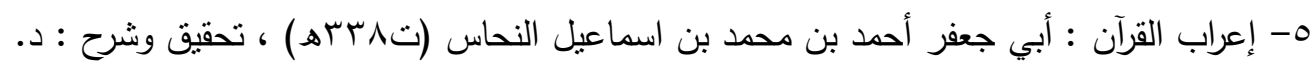

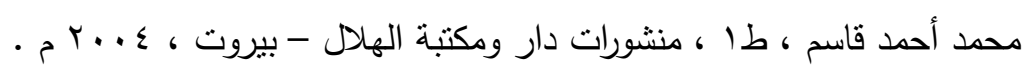

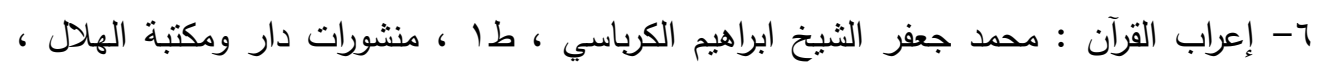

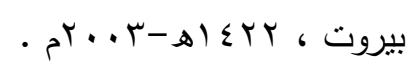

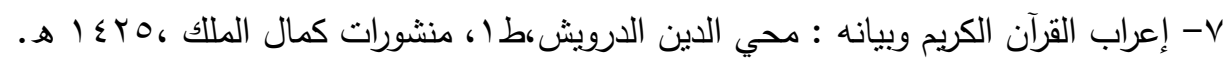

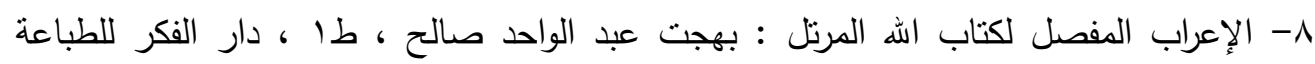

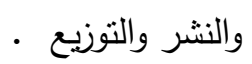

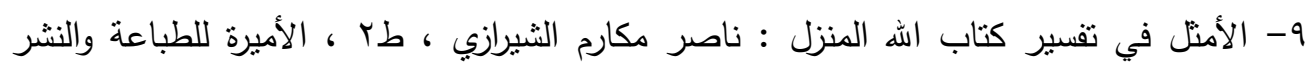

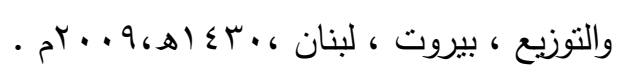

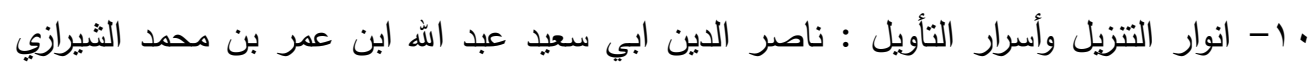

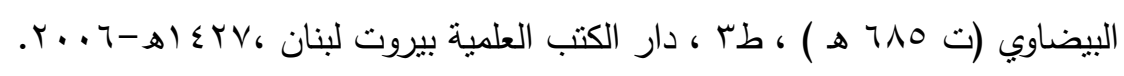

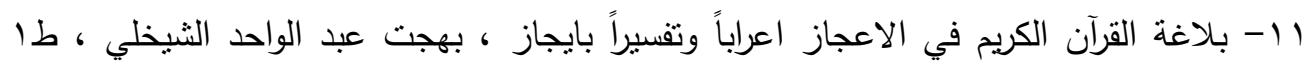

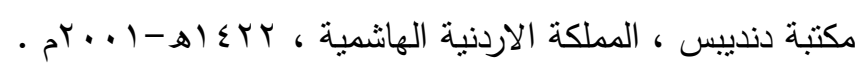

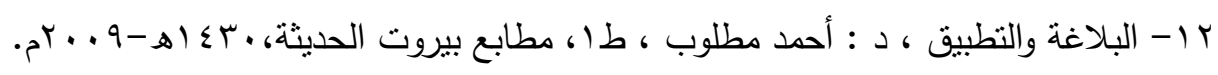


rا ا- التبيان في تفسير القرآن : أبي جعفر محمد بن الحسن الطوسي ( ت . بـ؛ هـ ) ، تحقيق الثيخ أغا يزرك الطهراني ، وأحمد حبيب قصير العاملي ، مؤسسة الأعلمي للمطبوعات ، بيروت.

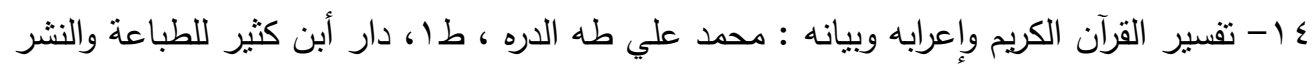

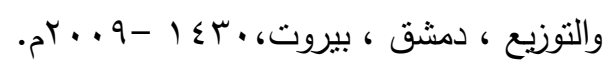

10- تفسير القمي : ابي الحسن علي بن ابراهيم القمي(ت وبrاهـ)،تحيح:السيد طيب الجزائري،طس

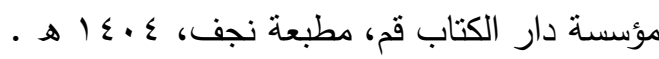

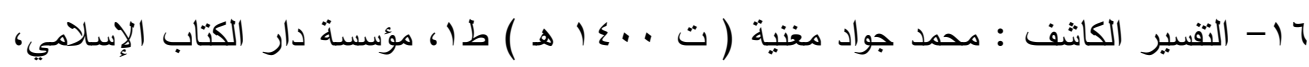
•

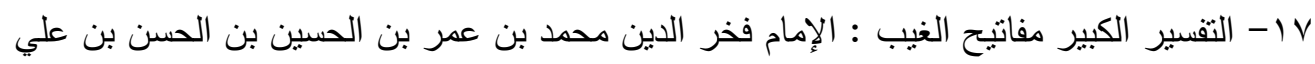

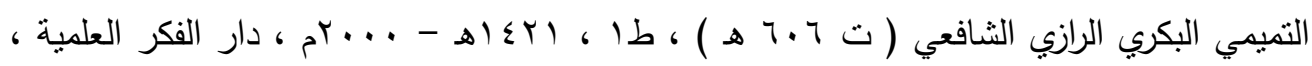
بيروت ، لبنان البكري البران

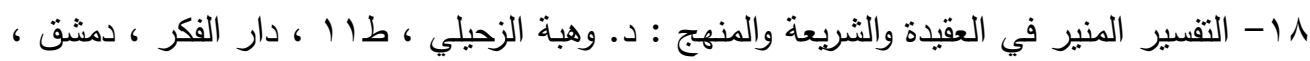

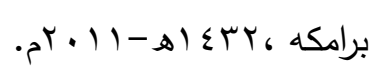

9 1 - تفسير مقتتيات الدرر : السيد مير علي الحائري الطهراني ، تحقيق محمد نقي الهاشمي ، طا

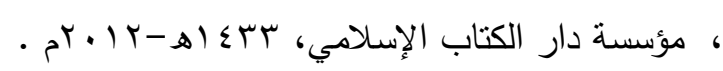

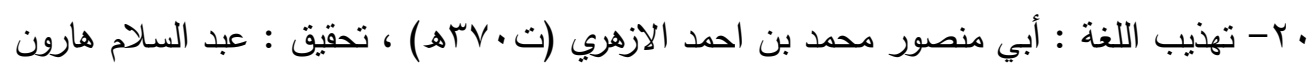

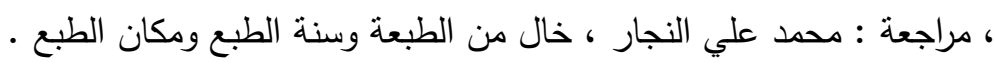

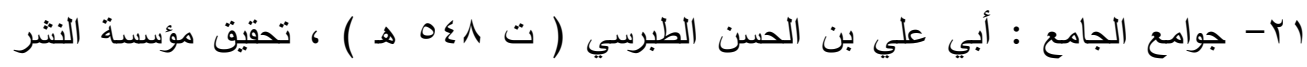

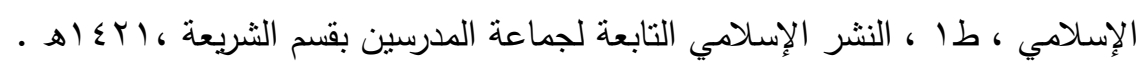

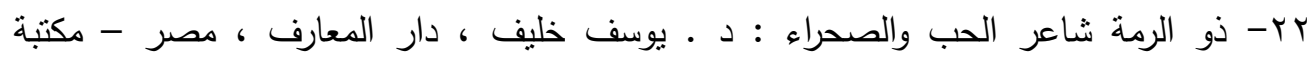

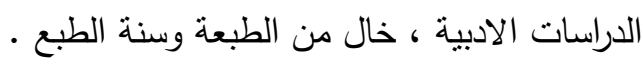




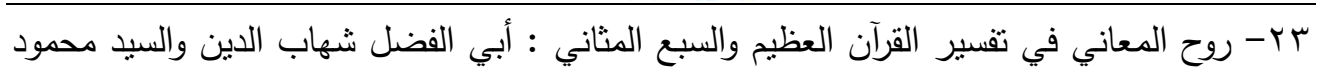

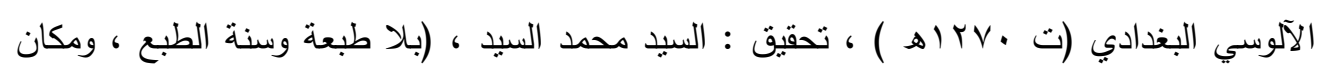
الطبع ) الالبني الطغ

ـ ؟- علم البديع ، دراسة تأريخية وفنية لأصول البلاغة ومسائل البديع : بسيوني عبد الفتاح ، طب ،

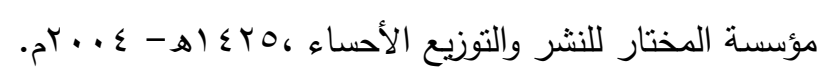
Or- علم المعاني : قصي سالم علوان : أيضا لم يذكر المعلومات : الطبعة وسنة الطعار الطبع ومحل - الطبع

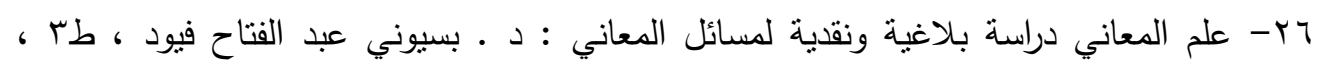

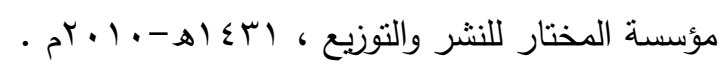

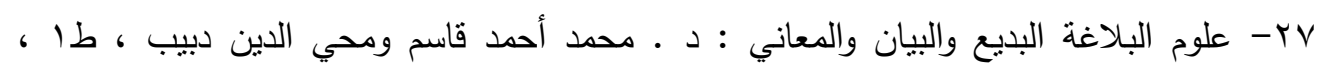

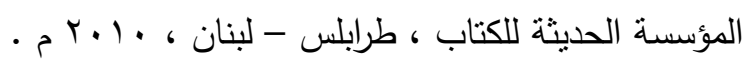

^ץ- الفرقان في تفسير القرآن والسنة : د . . محمد الصادقي ، ط، الامبره للطباعة والنشروالتوزيع،بيروت

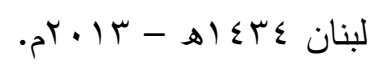

وr- كتاب الحلل في اصلاح الخلل من كتاب الجمل : أبي محمد عبد الله بن محمد بن السيد

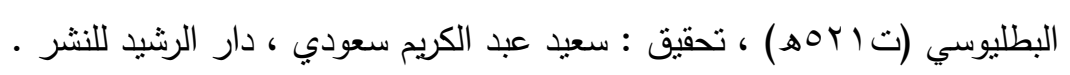

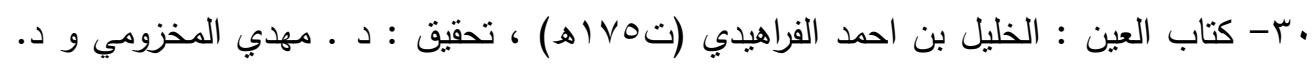

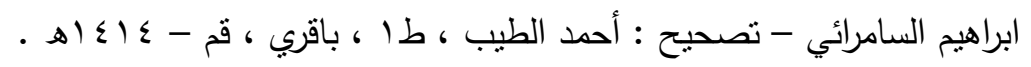

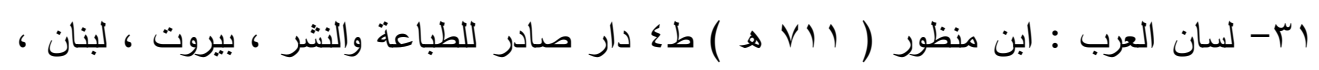
.

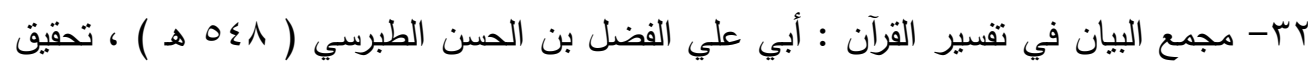

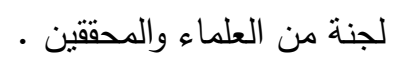

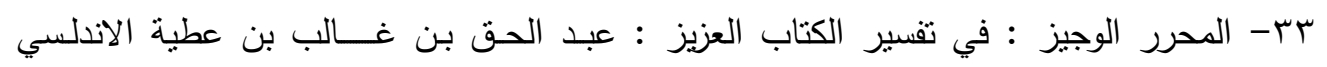

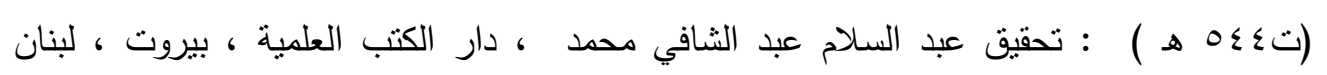
$\left.\cdot r^{\top} \cdot \nabla-\Delta\right) \leq r \Lambda$

نيسان 10. T

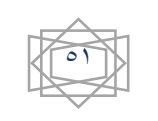




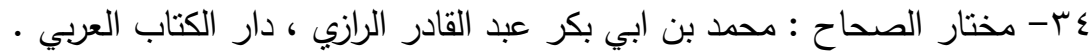

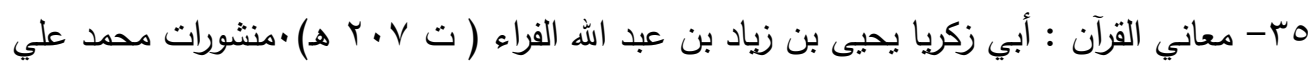

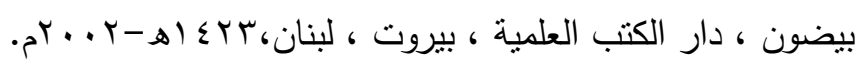
جس- معاني القرآن وإعرابه ، المختصر في إعراب القرآن ومعانيه ، ابي إسحاق إبراهيم بن محمد بن السري الزجاج البغدادي ( ت Iاس هـ ) : تحقيق أحمد فتحي عبد الرحمن : دار الكتب العلمية ،

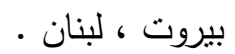

V V - معجم الصحاح : اسماعيل بن حماد الجوهري : اعتتى به خليل مأمون شما ، طب ، دار

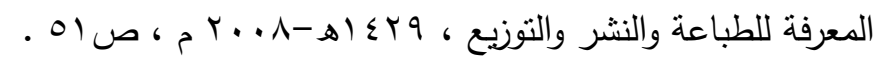
^ז- مقاييس اللغة : ابي الحسين أحمد بن فارس بن زكريا(تهوب هـ)، تحقيق : عبد السلام محمد وهد

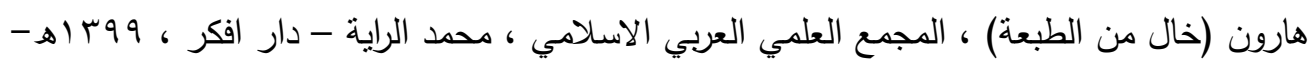
- $19 \vee 9$

qr- من هدي القرآن الكريم : محمد تقي المدرسي ، طب، دار القارئ للطباعة والنشر والتوزيع . $r$. . 